\title{
Microbial responses to unconventional oil and gas development may alter ecosystem function in headwater streams
}

\author{
Rachel Michaels \\ rlmichaels@mix.wvu.edu
}

Follow this and additional works at: https://researchrepository.wvu.edu/etd

Part of the Environmental Microbiology and Microbial Ecology Commons, Oil, Gas, and Energy

Commons, and the Water Resource Management Commons

\section{Recommended Citation}

Michaels, Rachel, "Microbial responses to unconventional oil and gas development may alter ecosystem function in headwater streams" (2020). Graduate Theses, Dissertations, and Problem Reports. 7900.

https://researchrepository.wvu.edu/etd/7900

This Thesis is protected by copyright and/or related rights. It has been brought to you by the The Research Repository @ WVU with permission from the rights-holder(s). You are free to use this Thesis in any way that is permitted by the copyright and related rights legislation that applies to your use. For other uses you must obtain permission from the rights-holder(s) directly, unless additional rights are indicated by a Creative Commons license in the record and/ or on the work itself. This Thesis has been accepted for inclusion in WVU Graduate Theses, Dissertations, and Problem Reports collection by an authorized administrator of The Research Repository @ WVU. For more information, please contact researchrepository@mail.wvu.edu. 
Graduate Theses, Dissertations, and Problem Reports

2021

Microbial responses to unconventional oil and gas development may alter ecosystem function in headwater streams

Rachel Michaels

Follow this and additional works at: https://researchrepository.wvu.edu/etd

Part of the Environmental Microbiology and Microbial Ecology Commons, Oil, Gas, and Energy Commons, and the Water Resource Management Commons

ठ 



\title{
Microbial responses to unconventional oil and gas development may alter ecosystem function in headwater streams
}

\author{
Rachel Michaels \\ Thesis submitted to the \\ Davis College of Agriculture, Natural Resources and Design \\ at West Virginia University \\ in partial fulfillment of the requirements for the degree of \\ Master of Science in Applied and Environmental Microbiology \\ Ember Morrissey, Ph.D., Chair \\ Michael Strager, Ph.D. \\ Paul Ziemkiewicz, Ph.D. \\ Todd Petty, Ph.D.
}

Division of Plant and Soil Sciences

Morgantown, West Virginia

2020

Keywords: Microbial Community Composition, Biogeochemistry, Headwater Stream Ecosystem, Unconventional Oil and Natural Gas, Carbon Cycling, Biofilms

Copyright 2020 Rachel Michaels 


\section{Abstract \\ Microbial responses to unconventional oil and gas development may alter ecosystem function in headwater streams}

\section{Rachel Michaels}

The demand for natural gas, and the need for efficient extraction, has led to the development of unconventional oil and natural gas (UOG) techniques. Due to the novelty of UOG, the potential impacts to freshwater ecosystems are not fully understood. We used a dual pronged approach to study the effects of UOG development on microbial biodiversity and function via a laboratory microcosm experiment and a survey study of streams with and without UOG development within their watersheds. The laboratory microcosm study simulated stream contamination with produced water, a byproduct of UOG operation, using sediment collected from one high water-quality stream and two low water-quality streams. For the survey study, biofilm and sediment samples were collected from streams experiencing varying levels of UOG development. In the microcosm study, microbial community composition differed significantly between streams, and produced water altered microbial function. Specifically, there was a negative effect on microbial aerobic and anaerobic $\mathrm{CO}_{2}$ production in the high water-quality stream sediment but a positive effect on this microbial activity in the lower water-quality stream sediments, suggesting habitat degradation alters the response of microbes to contaminants. Results from the stream survey study indicated UOG development alters aerobic and anaerobic $\mathrm{CO}_{2}$ production, microbial community composition, as well as stream water temperature and chemistry. Correlations among UOG associated land use, environmental, and microbial variables suggest increases in light availability and sediment delivery to streams, due to deforestation and land disturbance, impact stream microbial communities and their function. Consistent changes in the proportional abundance of bacterial families suggest microorganisms may be good indicators of the environmental changes associated with UOG development. The observed impacts of UOG development on microbial community composition and carbon cycling could have cascading effects on stream health and broader ecosystem function. 


\section{Acknowledgement}

I would like to thank my advisor, Dr. Ember Morrissey, for giving me the opportunity to grow as a scientist by studying a subject I deeply care about. I would also like to thank Kevin Eliason for creating a positive field work environment and being available to answer my many questions. Dr. Todd Petty, Dr. Michael Strager, Dr. Paul Ziemkiewicz, and Dr. Charlene Kelly also have my thanks for their guidance and insight during this project. I am grateful that I had the opportunity to work with fellow lab members Chansotheary Dang, Jeth Walkup, Kieran Liseki, Juan Pineiro Nevado, Teagan Kuzniar, April Kessel, and Ben Kiem. They made me laugh on a daily basis, and I cannot thank them enough for that. Finally, I want to thank my sister, Allison, for her support and patience. She listened to me prepare for countless presentations just so I would have an audience and attended all that she could. 


\section{Table of Contents}

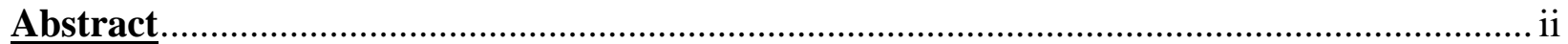

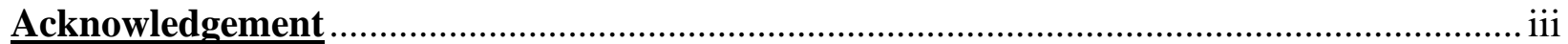

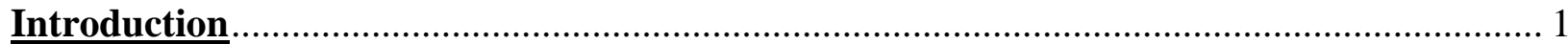

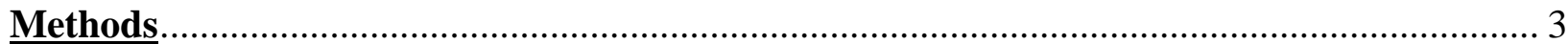

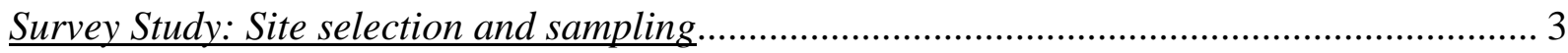

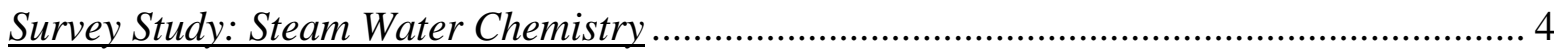

Survey Study: Sediment Characterization ……………................................................... 4

Microcosm Experiment: Site selection and sample collection …………............................... 5

Microcosm Experiment: Laboratory Treatments and Conditions.......................................... 6

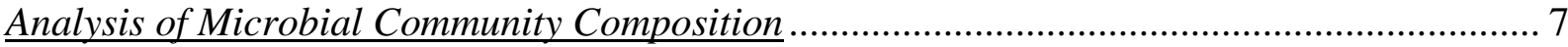

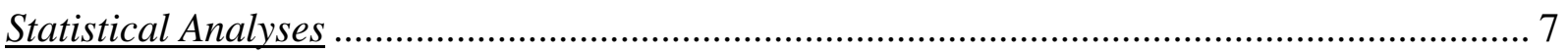

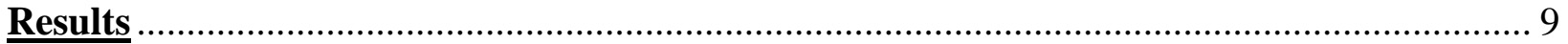

Produced Water Microcosm Experiment ………………...................................................... 9

Survey of Streams in Response to Watershed UOG Development …………………............... 9

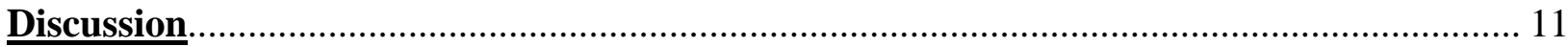

Conclusion

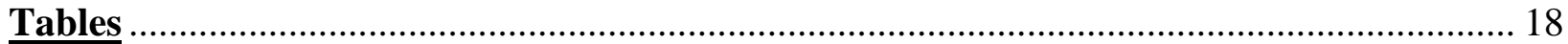

Figures

References 


\section{Introduction}

Hydraulic fracturing, a method of unconventional oil and gas (UOG) extraction, alters land use within watersheds and may impact microbial processes in headwater streams. Headwater streams are biogeochemically active systems due to their hydrological regimes and bacterial communities in sediment and biofilm (Battin et al., 2016; Harjung et al., 2019). These communities are recognized as major contributors to both the carbon and nitrogen cycle through the degradation of organic matter, carbon fixation, primary productivity, the uptake and denitrification of nitrate in streams, making them crucial to stream ecosystem function (Kasting \& Siefert, 2002; Battin et al., 2016; Fellows et al., 2006).

Headwater streams have high connectivity with surrounding terrestrial ecosystems through allochthonous inputs (e.g., dissolved nutrients, fine and course particulate organic matter) which influence not only the physical and chemical characteristics of streams but also their biodiversity and productivity (Lowe \& Likens, 2005). Due to this connectivity, headwater streams are particularly vulnerable to environmental disturbances occurring within watersheds (Lowe \& Likens, 2005). Microbial communities in headwater stream ecosystems are of particular interest for assessing environmental perturbations because anthropogenic stress is often observed at the lowest trophic levels, and microorganisms can readily adapt to environmental conditions (Nuy et al., 2018).

Recent research has identified that natural gas in the United States is largely retrieved from the Marcellus Shale formation, which underlies the highly forested Appalachian Basin and encompasses large parts of New York, Pennsylvania, and West Virginia and extends into Ohio, Maryland, and Virginia. Development includes land alteration in the interest of creating of access roads, gathering lines, storage areas, and a well pad site, affecting approximately 9 acres of forested area per well pad installation (Johnson et al., 2010). Decreases in forest coverage can increase surface water runoff and potentially alter the hydrological regimes of nearby streams, causing increased deposition of fine sediment particles (e.g., silt and clay) and altered physiochemical characteristics (e.g., temperature and dissolved oxygen) (Kiviat, 2013; Allen et al., 2003). This may change nutrient inputs associated with fine sediments and water conditions suitable for sustaining resident biotic communities, and pollutants associated with fine sediments and dissolved organic matter may be delivered to streams via runoff where they are introduced to 
stream microbial communities. (Eggleton \& Thomas, 2004). Anthropogenic pollutants introduced to stream microbial communities may affect microbial respiration in sediments as well as biofilm and sediment bacterial community composition (Hill et al., 2002; Feris et al., 2003; Ancion et al., 2013). Headwater stream ecosystems undergoing deforestation may experience shifts in heterotrophic and autotrophic activity, disrupting food web linkages to terrestrial ecosystems by altering the availability of allochthonous carbon in headwater streams (England \& Rosemond, 2004; Bengtsson et al., 2018). As a result, heterotrophic bacteria may rely more on autochthonous organic compounds produced within the stream by phytoplankton or autotrophic organisms in biofilms. This challenges the River Continuum Concept (RCC) which states that headwater stream food webs are supported by allochthonous inputs due to high forest coverage and limited light to support autochthonous production by algae (Vannote et al., 1980).

Following well pad borehole creation, fracturing fluid containing chemical additives and propping agents is injected into the borehole at high pressure, fracturing the shale formation. In the Appalachian Basin, up to $36,620 \mathrm{~m}^{3}$ of fracturing fluid is used per well (Gallegos et al., 2015). Water required for fracturing fluid may be extracted from groundwater reserves in close proximity to the operation, lowering the water table and altering hydrologic flows of nearby streams (Brittingham et al., 2014). When injected fracturing fluid returns to the surface via the borehole, the flowback water carries some naturally occurring water from within the shale formation. After most of the injected fluids have returned to the surface, produced water from the well is dominated by the aqueous geochemistry of the shale formation. This "produced water" is a hypersaline brine that contains hydrocarbons, oil, bitumen, barium, strontium, radioactive radium, arsenic, and selenium. The total dissolved salt content of produced water exiting the Marcellus Shale formation can be up to $180,000 \mathrm{mg} / \mathrm{L}$, making it roughly 7 times saltier than seawater $(25,000 \mathrm{mg} / \mathrm{L})$ (Vengosh et al., 2014). It is predicted that UOG production in the United States will double by 2035 and the practice will continue to spread globally (Vengosh et al., 2014). The impacts of UOG development, due to land alteration or spills of produced water, on surrounding freshwater ecosystems is not well understood due to the recent origination of UOG extraction methods.

The aim of this study was to determine if and how unconventional oil and gas development impacts stream health by examining microbial community composition and 
function. We hypothesized that streams with high levels of UOG development would have altered biodiversity and impaired function due to changes in stream and/or sediment physiochemical properties associated with UOG development. To accomplish our aim, we used a dual pronged approach consisting of a laboratory microcosm experiment to test the effects of produced water on sediment communities and a survey of streams experiencing varying levels of watershed UOG development.

\section{Methods}

The laboratory microcosm study simulated stream contamination with produced water, a byproduct of UOG operations (Vengosh et al., 2014), using sediment from three freshwater streams (one with high water-quality and two with low water-quality). For the survey study, sediment and biofilm samples were collected from 20 streams with UOG development and 7 reference streams. In both studies, microbial activity was assessed by measuring the production of $\mathrm{CO}_{2}$ (aerobic and anaerobic) and $\mathrm{CH}_{4}$ (anaerobic), and prokaryotic community composition was examined via Illumina amplicon sequencing of the 16S rRNA gene.

\section{Survey Study: Site selection and sampling}

Forested headwater streams were selected as study sites $(n=27)$ and had either UOG development within their watershed $(n=20)$ or did not have any influence of UOG development $(n=7)$. At the time of sampling, researchers were unaware of impact status. Sites were sampled during baseflow conditions in July and August of 2019. Along the stream bank, 3 sediment cores ( 500g soil) were collected below water level similar to Trexler et al., (2014) using a 1-inch soil corer, and $5 \mathrm{~mL}$ of biofilm was collected from the stream substrate at each study site by removing cobble from riffles, runs, shallow pools, and nearshore habitats and collecting biofilm through abrasion using a laboratory spatula and similar to Lear et al., (2008). Additionally, $1 \mathrm{~L}$ of stream water was collected mid-stream using a sterile container. Sediment cores were homogenized and used for sediment characterization and microbial analyses. Sediment, water, and biofilm samples were transported on ice until lab processing.

The intensity of UOG development in each watershed was quantified by landscape mapping. Parameters of interest included the number of well pads, acres of pipeline, and land use 
associated with UOG development. Watershed data also included coal mining records to control for compounded impact of UOG activity and mining.

Survey Study: Steam Water Chemistry

Stream water conductivity, temperature, and $\mathrm{pH}$ were determined during field sampling using a hand-held probe (YSI 650 equipped with a 600XL sonde Yellow Springs Instruments, Yellow Springs, Ohio). Water oxidation-reduction potential was determined during lab processing using handheld probe FiveGo F2 (Mettler Toledo, (Columbus, Ohio)). A single filtered sample was obtained using a Nalgene filtration device with a $0.45 \mu \mathrm{m}$ mixed celluloseester membrane filter. This sample was used to measure Al, $\mathrm{Ca}, \mathrm{Fe}, \mathrm{Mg}, \mathrm{Mn}, \mathrm{K}, \mathrm{Na}, \mathrm{Sr}, \mathrm{Zn}$ (EPA method 200.7) as well as Ba, Cd, Cr, Ni and Se. (EPA method 200.8). Three unfiltered samples were obtained and used to measure $\mathrm{Br}^{-}, \mathrm{Cl}^{-}, \mathrm{SO}_{4}{ }^{2-}$ (EPA method 300.0), $\mathrm{N}\left(\mathrm{NO}_{2}{ }^{-}\right.$and $\left.\mathrm{NO}_{3}{ }^{-}\right)(\mathrm{EPA}$ method SM4110B-2000), total P (EPA method SM4500-P BE-1999), total dissolved solids (TDS) (EPA method SM2540 C-1997), and total and bicarbonate alkalinity (EPA method SM2320 B-1997). Samples were stored at $4^{\circ} \mathrm{C}$ until analysis by an NELAP accredited laboratory (Pace Analytical Services, WV). Method detection limit (MDL) was reported in $\mathrm{mg} / \mathrm{L}$ for all analyses. $\mathrm{Al}$ (0.006), $\mathrm{Ca}, \mathrm{Mg}$, and $\mathrm{K}$ (0.050), Fe (0.010), Mn (0.003), $\mathrm{Na}$ (0.100), Sr (0.001), Zn (0.004), Ba (0.0020), Cd (0.00005), Cr, Ni, and Se (0.0010), $\mathrm{Br}^{-}(0.05), \mathrm{Cl}^{-}(0.20), \mathrm{SO}_{4}^{2-}(1.00)$, $\mathrm{N}(0.150)$, total P (0.01), TDS (5), and bicarbonate alkalinity (1.0).

\section{Survey Study: Sediment Characterization}

Particle size analysis of stream sediment was assessed using the hydrometer method adapted from the Kellogg Biological Station Long-Term Ecological Research Particle Size Analysis for Soil Texture Determination Protocol (Hydrometer Method) (2008). Briefly, sediment $(50 \mathrm{~g})$ was air-dried and pulverized to pass through a $<2 \mathrm{~mm}$ sieve and $250 \mathrm{~mL}$ of deionized water and $20 \mathrm{~mL}$ of sodium hexametaphosphate was then added to the sediment. The suspension was transferred to a sedimentation cylinder where deionized water and a hydrometer was added to bring the total volume to $1 \mathrm{~L}$. The hydrometer was removed, and the mixture was capped and mixed several times through inversion. After mixing, the hydrometer was inserted, and after 30 seconds, the hydrometer was read. This was repeated three times to determine sand content. On the third read, the hydrometer remained in the cylinder. After two hours, a final 
measurement was recorded to determine silt content, and the difference between 100 percent and the sum of the percentage of sand and silt content was calculated as clay content. Percent organic matter was determined by measuring mass loss on ignition after combustion at $500^{\circ} \mathrm{C}$ for 5.5 hours (Morrissey et al., 2013). Stream sediment oxidation-reduction potential, $\mathrm{pH}$, and conductivity were measured using handheld probes during lab processing (oxidation-reduction potential and pH, FiveGo F2 (Mettler Toledo, (Columbus, Ohio)); conductivity, Pocket Pro (Hach, Loveland Colorado).

Microbial function was assessed by measuring aerobic and anaerobic stream sediment heterotrophic respiration rates in laboratory microcosms (sensu Neubauer et al., 2005). Briefly, moist sediment $(7.0 \pm 0.2 \mathrm{~g})$ was combined with $7 \mathrm{~mL}$ of sterilized stream water $(0.22 \mu \mathrm{m}$ nylon membrane filter) collected in concert with the sediment in a $164 \mathrm{~mL}$ sterile serum bottle at $22^{\circ} \mathrm{C}$. If measuring anaerobic respiration, the headspace was flushed with $\mathrm{N}_{2}$ for at least two minutes, and sterilized stream water was deoxygenated in capped sterile serum bottles for at least 2 minutes. Gas samples were taken at 0, 24, and 48 hours. Respiration rates were linear, with average $\mathrm{r}^{2}>0.93\left(\right.$ aerobic $\left.\mathrm{CO}_{2}\right), 0.83$ (anaerobic $\mathrm{CO}_{2}$ ), and 0.78 (anaerobic $\mathrm{CH}_{4}$ ).

\section{Microcosm Experiment: Site selection and sample collection}

To determine the effect of produced water on sediments, three streams were selected to represent systems of varying water quality. Sites were selected using ten years of historical data obtained from 3 Rivers QUEST (https://3riversquest.wvu.edu/). The three sites included a high water quality stream (White Day) and two streams with lower water quality (Ten Mile and Whitely). Streams of varying water quality were selected to determine the effect of produced water on sediments exposed to varying environmental conditions. Three reaches $(10 \mathrm{~m})$ were established on each stream, within each reach a minimum of three sediment cores were collected to achieve $\sim 500 \mathrm{~g}$ of sediment. Approximately 5 gallons of water was collected at each site from mid-stream using sterile containers. Sediment and water samples were transported on ice until lab processing. Sediment samples from each reach were homogenized.

Produced water was obtained from West Virginia University's Water Research Institute and originated from Marcellus Shale Energy and Environmental Laboratory Well 3H on May 6, 2019. The produced water sample was determined to have the following chemistry reported in 
mg/L unless otherwise stated: $\mathrm{Br}$ (617.86), SO4 (<0.33), $\mathrm{Cl}(66,022.00)$, TDS(111,724.00), Total suspended solids (76.00), Alkalinity (0.68), Ba (4,802.14), Ca (10,305.11), Fe (114.87), K (212.06), $\mathrm{Li}$ (30.09), $\mathrm{Mg}$ (967.17), $\mathrm{Mn}$ (4.63), $\mathrm{Na}$ (21.416.37), $\mathrm{Sr}$ (2,090.63), conductivity 138.300.00 $(\mu \mathrm{S} / \mathrm{cm}), \mathrm{pH}$ 5.92. Water chemistry was reported by the National Research Center for Coal and Energy using EPA protocols as described above for the survey study.

\section{Microcosm Experiment: Laboratory Treatments and Conditions}

To determine the effect of produced water on sediment prokaryotic communities, laboratory microcosms were established under aerobic and anaerobic conditions with three levels of produced water $(0 \%, 0.5 \%, 5 \%)$. Stream water from each site was filter sterilized using a 0.22 $\mu \mathrm{m}$ nylon membrane filter paper then combined with filter sterilized produced water to create treatments of $0 \%, 0.5 \%$, and 5\% produced water. Moist sediment from each sampling reach (20 $\pm 0.2 \mathrm{~g}$ ) of each stream was combined with $20 \mathrm{~mL}$ of each treatment in $164 \mathrm{~mL}$ sterile serum bottles. The serum bottle headspace was flushed with $\mathrm{N}_{2}$ for at least two minutes if under anaerobic conditions.

Microcosms were stored in the dark at $22^{\circ} \mathrm{C}$ with headspace gas sampling and treatment water replacements every 3-4 days for three weeks (Yakimov et al., 2005; Kelly et al., 1999). Treatment water was refreshed by removing $10 \mathrm{~mL}$ of overlying water and adding $10 \mathrm{~mL}$ of newly made treatment water. If under aerobic conditions, treatment replacements were conducted by removing microcosm caps to allow the headspace to exchange with atmospheric $\mathrm{CO}_{2}$ and recapped once the replacement was made. Anaerobic microcosms were maintained by removing and replacing treatment water from sealed serum bottles using sterile syringes. After gas sampling, anaerobic headspaces were flushed with $\mathrm{N}_{2}$ for at least two minutes to return the headspace gas to a known concentration prior to treatment water replacement. Replacement treatment water was deoxygenated by flushing with $\mathrm{N}_{2}$ for at least two minutes and added to microcosms using sterile syringes. After the three-week incubation, sediment from microcosms was collected using sterile spatulas and stored in sterile Whirl-pak bags at $-20^{\circ} \mathrm{C}$ until DNA extraction.

\section{Gas Sampling and Analysis}

Aerobic $\mathrm{CO}_{2}$ production was measured by injecting $10 \mathrm{~mL}$ of air and extracting $10 \mathrm{~mL}$ of 
headspace. If measuring anaerobic respiration, $60 \mathrm{~mL}$ of $\mathrm{N}_{2}$ was injected and $60 \mathrm{~mL}$ of headspace was removed. After collection, aerobic samples were immediately run on a LICOR LI-6400 fitted with a trace gas sampling kit (LI-COR, Lincoln, NE) to measure $\mathrm{CO}_{2}$ concentration, and anaerobic samples were run on a Piccaro G2201-I (Picarro Inc., Santa Clara, CA) to measure $\mathrm{CO}_{2}$ and $\mathrm{CH}_{4}$ concentrations. Headspace carbon gas concentrations were calculated through comparison to a standard curve of known $\mathrm{CO}_{2}$ concentrations $(0 \mathrm{ppm}$, 400ppm, 1,000ppm, and 50,000ppm), and $\mathrm{CH}_{4}$ concentrations (0 ppm, 10ppm and 100ppm).

\section{Analysis of Microbial Community Composition}

The Qiagen PowerSoil DNA Isolation Kit (Carlsbad, CA, USA) was used for sediment and biofilm DNA extractions per the manufacturer's instructions. The purity and concentration of the DNA was assessed through PicoGreen assay using Biotek Synergy HTX Multi-Mode MicroPlate Reader (BioTek Instruments Inc., Winooski, VT). All reactions were performed in triplicate, and the final reaction volume consisted of $1 \mu \mathrm{L}$ of DNA template, $10 \mu \mathrm{L}$ PicoGreen (manufacturer) and $9 \mu \mathrm{L} 1 \mathrm{X}$ TE buffer. Final extracts were stored at $-20^{\circ} \mathrm{C}$. Microbial community composition was analyzed by targeting the hypervariable V4 region of the 16S rRNA gene. Batch normalization of qPCR products was performed using Invitrogen SequalPrep DNA Normalization plates (Applied Biosystems ${ }^{\mathrm{TM}}$, Waltham, Massachusetts, USA), and AMPureXP magnetic beads (Beckman Coulter, Brea, CA, USA) were used to pool and cleanup recovered products. Sequencing was performed on a MiSeq standard v2 flow cell in a 2x250bp paired end format. Illumina Real Time Analysis (RTA) (v1.18.54) was used for base calling (RTSF Genomics Core, Michigan State University, MI).

\section{Statistical Analyses}

To analyze microbial community data, the 16S rRNA gene amplicon forward and reverse sequences were imported in to QIIME2 (2019.7; Bolyen et al., 2019). Reads were demultiplexed and merged using VSEARCH to produce paired-end reads (Rognes et al., 2016). Sequences were quality filtered using a quality score of 20 to remove bases from the dataset that had less than 99 percent certainty. Deblur was then used to correct amplicon sequence errors and filter chimeric sequences (Amir et al., 2017). DNA sequences from the resulting amplicon sequence variants 
(ASVs) were then matched to their respective taxon using the QIIME2 feature classifier (classify-sklearn; Bokulich et al., 2018) ASVs were used to calculate $\alpha$ and $\beta$ diversity metrics.

For the survey study, streams were classified based on level of impact using GIS data collected on May 11, 2020 from West Virginia Geological and Economic Survey's oil and gas well database. UOG development was quantified in the local catchment of the stream using the acres of pipeline, number of complete wells, and land use classified as Oil and Gas Barren. Streams with no UOG development were considered non-impacted, impacted streams had below average development occurring within the local watershed, and highly impacted streams had above average development (defined as pipeline area > 106.9, number of completed wells > 24.8, or acres of Oil and Gas Barren > 23,288) occurring within the local watershed. Data distribution was determined using Shapiro-Wilk Normality Test ('shapiro.test' function, Royston, 1982a, 1982b, 1985). Depending on data distribution, either analysis of variance (ANOVA; 'aov' function, Chambers, 1992) along with Least Significant Difference post hoc ('LSD.test' function in the 'aricolae' package; Steel \& Torrie, 1986, De Mendiburu 2020) or Kruskal-Wallis Rank Sum Test ('kruskal.test' function in the 'agricolae' package; Hollander \& Wolfe, 1973), along with Dunn's Kruskal-Wallis Multiple Comparisons post hoc ('dunnTest' function in the "FSA" package; Dunn, 1964, Ogle et al., 2020) was used for univariate response variables (e.g. respiration) in the survey and microcosm study. Additionally, Bartlett (parametric, 'bartlett.test' function, Bartlett, 1937) or Fligner-Killeen (non-parametric, 'fligner.test' function, Conover et al., 1981) test of Homogeneity of Variances was applied to data depending on distribution to assess group variances in the survey study. Relationships between metrics of UOG development intensity and environmental and microbial community parameters was explored using Spearman correlation. Bray-Curtis dissimilarities (in the relative abundance of ASVs) was used to discern differences in community composition with respect to impact status in the survey study and treatments in the microcosm study using permutational multivariate analysis of variance (PerMAONVA; 'adonis' function in the 'vegan' package; Oksanen et al., 2019, Anderson, 2001, Excoffier et al., 1992, Legendre \& Anderson, 1999, McArdle \& Anderson, 2001, Warton et al., 2012; Anderson, 2017). Bray-Curtis dissimilarities were visualized using principal coordinates analysis $(\mathrm{PCoA})$ and used to assess within group $\beta$-diversity in the survey study. Shannon diversity index was determined to assess $\alpha$-diversity ('diversity' function in the 'vegan' package; Fisher et al., 1943, Hurlbert, 1971). Indicator species analysis was performed to 
identify families whose relative abundance was significantly different from at least one other impact level using the 'indval' function in the 'labdsv' package (Roberts, 2019; Dufrêne \& Legendre, 1997). The mean relative abundances of these taxa were used to calculate a response ratio as a way to visualize the effect of UOG development on each organism (Lajeunesse, 2011). All statistical analyses were performed in R version 3.6.3 (R Core Team, 2020).

\section{Results}

\section{Produced Water Microcosm Experiment}

Many water physiochemical properties differed significantly between the three streams utilized for the microcosm study (Table 1). In general, White Day (WD) creek had the best water quality with low concentrations of dissolved ions, total dissolved solids, conductivity and alkalinity while Ten Mile (TE) creek was intermediate and Whitely (WH) creek exhibited the highest values for these parameters. The addition of produced water had a negative effect on microbial aerobic and anaerobic $\mathrm{CO}_{2}$ production in sediment from the high water-quality stream (WD) but a positive effect on this microbial activity in the sediments obtained from the low water-quality streams (WH \& TE, Fig. 1). Effects were similar for both the low $\left(0.5 \mathrm{mg} \mathrm{L}^{-1}\right)$ and high $\left(5 \mathrm{mg} \mathrm{L}^{-1}\right)$ concentrations of produced water. The influence of produced water on microbial $\mathrm{CH}_{4}$ production was more variable (Fig. 1). Microbial community composition differed significantly between streams (PerMANOVA, $\mathrm{p}=0.001$ ). While produced water did not significantly alter overall community composition (PerMANOVA, $\mathrm{p}=0.082$ ), the relative abundance of thirty-three families changed significantly following the addition of produced water and were identified as indicators of treatment (Fig. 2, Indval, p<0.01). Seventeen families responded negatively to produced water, while sixteen responded positively to either the low $(0.5$ $\left.\mathrm{mg} \mathrm{L}^{-1}\right)$ or high $\left(5 \mathrm{mg} \mathrm{L}^{-1}\right)$ concentration of produced water when considering both aerobic and anaerobic conditions.

Survey of Streams in Response to Watershed UOG Development

A total of 27 streams were sampled and classified as non-impacted, impacted, or highly impacted based on the level of UOG development within the local watershed. Alkalinity was highest in impacted sites compared to those that were highly impacted and non-impacted (Table 
2, ANOVA, $\mathrm{p}<0.01$ ), as was TDS and calcium (Table 2, Kruskal-Wallis, $\mathrm{p}<0.05$ and $\mathrm{p}<0.01$, respectively). Differences in variance between groups were observed for chloride concentrations in stream water (Fligner-Killeen, $\mathrm{p}<0.05$ ) and sediment $\mathrm{pH}$ (Bartlett's K-squared, $\mathrm{p}<0.05$ ). These differences are due to high chloride levels in some impacted streams not observed in the highly impacted and non-impacted streams and elevated sediment $\mathrm{pH}$ values in some highly impacted streams that were not observed in streams in the other two groups. Water temperature was greatest in highly impacted sites (Table 2, ANOVA, $\mathrm{p}<0.01$ ).

Microbial community composition and function differed between impact levels. Aerobic and anaerobic $\mathrm{CO}_{2}$ production was higher in impacted streams compared to non-impacted streams (Fig. 3, Kruskal-Wallis, ANOVA, p <0.05). Biofilm and sediment prokaryotic community composition differed between groups (PerMANOVA, $\mathrm{p}=0.003$ and $\mathrm{p}=0.029$, respectively), and sediment within-group $\beta$-diversity was more variable in highly impacted streams compared to those that were non-impacted (Fig. 4E, ANOVA, p<0.01). These effects can be visualized on the principal coordinate analysis plot (PCoA) as highly impacted communities are shifted away from, or more dispersed than the non-impacted communities (Fig $4 \mathrm{~A}$ and D, respectively). Biofilm diversity was more variable in highly impacted sites (Fig. 4C Fligner-Killeen, $\mathrm{p}<0.05$ ) as some highly impacted streams displayed scores much lower than any of the impacted and non-impacted streams.

The sand content of stream sediments was negatively correlated with acres of UOG pipeline. Accordingly, the silt and clay content of stream sediments was positively correlated with the acres of UOG pipeline occurring within watersheds (Fig. 5). These changes in sediment texture covaried with microbial variables. Silt content was positively correlated with aerobic and anaerobic $\mathrm{CO}_{2}$ production while sand content was negatively correlated aerobic respiration (Fig. 5). Both sediment clay and sand contents covaried with biofilm community composition. Beyond sediment texture, water temperature was positively correlated with local oil and gas development in watersheds and covaried with biofilm community composition (Fig. 5). In stream sediments, community composition (represented by PCoA Axis 2) covaried with respiration as some impacted and highly impacted streams had high respiration and changes in composition (Fig. 6).

In order to identify indicators of UOG development, indicator taxa analysis was performed. Indicators were identified for all three impact categories for both biofilm and 
sediment communities. The relative abundance of thirty-one taxonomic families was lower in sites when UOG development was present in the watershed, while the relative abundance of thirty-four families was highest in the impacted streams while only two families were indicators of the highly impacted streams (Fig. 7, indval, p<0.01).

\section{Discussion}

UOG development requires land alteration to construct well pads, pipeline, access roads, and gathering lines. These land alterations, which reduce forest coverage, could impact streams by altering light availability or changing sediment delivery. Likewise, leaks or spills of produced water during UOG extraction activities could contaminate streams with organic compounds and salts (Vengosh et al., 2014), potentially impacting biological systems. We conducted a microcosm study exposing sediments to produced water and a survey study to assess the effects of UOG development on stream microbial community composition and function. We sought to compare microcosm study findings to survey study data in order to explore the possibility that the observed differences between impact groups in the survey study may be attributed to produced water entering streams.

The addition of produced water to sediment microcosms produced effects on microbial metabolic activity that were dependent on site (Fig. 1). Increased activity in lower water-quality streams suggests microbial communities in these streams (WH and TE) may be able to utilize organic compounds present in produced water such as oil, bitumen, and hydrocarbon condensates (Vengosh et al., 2014), potentially due to previous exposure. Alternatively, the increases in activity in lower water-quality streams may also be attributed to the release of dissolved organic carbon (DOC) from sediment facilitated by salts in produced water (Reemtsma et al., 1999). Microorganisms in the lower water-quality streams may be salt-tolerant due to relatively high concentrations of dissolved ions in these streams, this salt tolerance would allow them to use released DOC for metabolism. In contrast, microbial activity in the higher waterquality stream was inhibited by produce water, potentially due to salt intolerance (Wichern et al., 2006, Wong et al., 2008).

While produced water did not significantly change overall prokaryotic community composition; several families, identified as significant indicator taxa (Fig. 2), were responsive to 
the treatments. Our results suggest produced water affected the aerobic and anaerobic microcosms differently as there was little overlap in the indicator taxa under these two conditions. The indicator taxa that responded positively to produced water, such as Sphingomonadaceae and Methylomirabilaceae, may be benefitting from compounds present in produced water. For example, some members of the family Sphingomonadaceae are known to degrade hydrocarbon compounds, including those present in produced water (Vengosh et al., 2014; Leys et al., 2004). Similarly, members of Methylomirabilaceae are anaerobic methane oxidizers (Versantvoot et al., 2018) and may have consumed methane present in produced water during our experiment. While most of the indicator taxa differed between the anaerobic and aerobic conditions, Sphingomonadaceae responded positively and Gemmatimonadaceae responded negatively to produced water regardless of oxygen availability suggesting it may be appropriate to use these families as a bioindicators of produced water contamination in streams.

The survey of stream responses to watershed UOG development revealed no evidence of stream contamination with produced water. First, stream water chemistry in impacted and highly impacted streams (Table 2) was not consistent with the composition of produced water, which has elevated levels of barium and strontium (Vengosh et al., 2014). Secondly, there was no overlap in indicator taxa between the microcosm experiment and survey study (Fig. 2 and 7). Further, while impacts of UOG development were observed, correlations between microbial and environmental variables suggest these changes are likely due to other mechanisms of UOG impact. Lack of evidence for stream contamination with produced water suggests the efforts to mange produced water on site during UOG development, including on-site containment, blowout preventers, and waste transportation plans (Ziemkiewicz et al., 2014) may be effectively preventing spills and leaks into headwater streams.

Taken together, our stream survey results suggest that UOG impacts derive mostly from deforestation and land disturbance. Deforestation raises the water table and depletes chloride stocks in groundwater (Cook et al., 1989; Giménez et al., 2016). Because groundwater chloride concentrations are closely linked to that of stream water (Bernal et al., 2015), the lower chloride levels in highly impacted sites (Table 2) is likely a consequence of deforestation in these watersheds. Stream water temperature was also significantly elevated in highly impacted sites (Table 2), and previous research suggests that streams located in deforested watersheds 
experience greater mean temperatures compared to those in forested watersheds (Ilha et al., 2018). This is most likely due to decreased riparian forest cover, which increases light availability to streams. We found a correlation between biofilm community composition and temperature (Fig. 5). While temperature could influence composition directly, the relationship is more likely a consequence of changes in light availability (Bengtsson et al., 2018). Because many organisms within biofilm matrices are phototrophic, assemblage structure is partially controlled by light (Battin et al., 2016). While biofilm diversity was not significantly lower, some highly impacted streams with elevated water temperatures had comparatively low biofilm diversity (Fig 4C, Fig 5). This agrees with previous research suggesting that increased light availability is followed by a decrease in biofilm heterotrophic bacteria (Bengtsson et al., 2018). Verrucomicrobia, a family identified in the indicator species analysis (Fig. 7), decreased in abundance in impacted and highly impacted streams. Previous research suggests that Verrucomicrobia is an early colonizer of some aquatic substrates (Bengtsson et al., 2010). The lower abundance of this family in impacted and highly impacted streams may impede colonization of biofilms in those streams, impacting organic matter degradation and disrupting the carbon cycle. Changes in bacterial abundance have also been documented to be accompanied by a shift from allochthonous to autochthonous carbon utilization. Heterotrophic bacteria present in biofilms preferentially process labile autochthonous carbon made available by increased algal exudation under increased light availability in lieu of recalcitrant allochthonous carbon from terrestrial sources (Wagner et al., 2017) potentially altering biofilm bacterial community composition (Attermeyer et al., 2015). Preferential processing of autochthonous carbon may influence carbon fluxes as there is evidence that the presence of labile carbon in freshwater aquatic systems does not promote priming of allochthonous carbon (Wagner et al., 2017; Catalán et al., 2015). Changes in the production, availability, and decomposition of autochthonous and allochthonous carbon may alter carbon transfer from heterotrophic bacteria to higher trophic levels (Wagner et al., 2017; Collins et al., 2016). In streams experiencing reduced canopy cover, biofilm-consuming macroinvertebrates increase in abundance (Hawkins et al., 1982). This is likely due to increased primary production, which may be attributed to increased light availability. An increase in high-quality algal biomass and detritus may be available to macroinvertebrates for consumption as a result of increased primary production. Despite an increase in the abundance of some macroinvertebrates in response to increased light availability, 
it is possible that some biofilm-consuming macroinvertebrates are excluded from feeding areas, causing a decrease in abundance. For example, scrapers, which consume biofilm on rock surfaces, may be prevented from accessing their food source as increased light availability may allow for the formation of thick biofilm on stream rocks.

Acres of pipeline was correlated with changes in sediment texture in streams (Fig. 5). Specifically, pipeline area was positively correlated with silt and clay and negatively correlated with sand content. While not statistically significant, our results indicate that impacted and highly impacted streams generally displayed higher amounts of silt and clay, whereas the nonimpacted reference streams typically had higher amounts of sand (Table 2). It is possible that impacted and highly impacted streams have different sediment grain size proportions compared to non-impacted streams because rainfall transports silt and clay particles to streams after being exposed during development. These finer sediments are likely being delivered to impacted and highly impacted streams located in deforested watersheds because runoff transports silt and clay greater distances than sand (Meyer et al., 1995). Increased amounts of clay in streams decreases light penetration which decreases algal biomass and primary production as biofilms become entrapped in clay (Davies-Colley et al., 1992). The entrapment of biofilms in clay particles and decreased light penetration may explain the correlation between biofilm community composition and percent clay in our study (Fig. 5). Clay may also decrease water movement within biofilm matrices, creating anaerobic environments. This may explain why Anaerolineaceae, an anaerobic bacterium (Mcllroy et al., 2017), was an indicator of impact and more abundant in UOG developed groups (Fig. 7). Further, hydrologic connectivity of ground and surface water is critical to nutrient regulation in streams, and regulation is dependent upon the degree of connectivity. Fine sediments (e.g. silt and clay) cause blockages and decreases connectivity, whereas coarse sediments (e.g. sandy) allow for the greatest connectivity (Li et al., 2020). Coarse sediments allow for the delivery of more nutrients to surface water, whereas blockages caused by clay reduces connectivity and prevents delivery (Perujo et al., 2017). This influences nutrient availability to microorganisms in streams biofilms (Perujo et al., 2017) and may further explain our correlations between sediment grain size and biofilm community composition.

Sediment texture also displayed correlations with sediment microbial activity. Sand content was negatively correlated with aerobic $\mathrm{CO}_{2}$ production, while both aerobic and anaerobic 
$\mathrm{CO}_{2}$ production were positively correlated with silt content (Fig. 5). These correlations agree with previous studies that demonstrated higher microbial respiration rates in finer textured soils compared to sandy soils (Dilustro et al., 2005; Hamarashid et al., 2010; Bouma \& Bryla, 2000). Changes in silt content could underlie the augmented aerobic and anaerobic $\mathrm{CO}_{2}$ production in the impacted streams sediments (Fig 3) since they also had the greatest average silt content (Table 2). Fine textured sediments likely have higher organic matter concentrations associated with them (Christensen \& Sørensen, 1985), which may explain the higher respiration rates observed in the impacted sites. Alternatively, enhanced respiration rates in the impacted and highly impacted streams could be a consequence of environmental stress. Microbes exhibit increased respiration per unit biomass (Metabolic quotient) in disturbed environments (Anderson $\&$ Domsch, 1993), presumably due to greater energy expenditure toward maintenance rather than growth (Ely et al., 2010). Enhanced microbial activity and reduced diffusion with fine sediments can both lower benthic oxygen levels potentially impacting higher trophic levels. Indeed, greater amounts of fine textured sediments in streams has been shown to have negative impacts on macroinvertebrate diversity and density (Lawrence \& Ward, 1982; Couceiro et al., 2009), possibly due to lower levels of dissolved oxygen in stream sediments (Tagart 1984).

Sediment and biofilm community composition differed by impact status. Highly impacted streams had more variable $\beta$-diversity in sediment communities and $\alpha$-diversity biofilm communities (Fig. 4E and C, respectively). Some impacted and highly impacted streams were very different from non-impacted streams, which explains this variability. It is possible that deviant impacted and highly impacted streams have differing landscape attributes, such as slope and hydrology, that may be determining sediment and nutrient delivery (Sheridan \& Loch, 2003; Sheridan \& Noske, 2007) and augmenting the impact of UOG development. Along the same lines, UOG development may have a disproportionate impact on some stream segments in the local catchment due to proximity or topography. Since we only sampled a small stream reach within catchments, our sampling effort may have been insufficient to consistently detect the impacts of UOG. This may explain why some communities in impacted and highly impacted streams did not display differences from non-impacted streams, while others were very distinct.

In the survey study, impacted streams generally had poorer water quality (elevated EC, TDS and Alkalinity, and Calcium, Table 2) and increased respiration (Fig. 3), relative to the 
highly impacted sites. Development in impacted watersheds may be contributing to the observed changes in water chemistry and respiration via elevated organic matter delivery associated with fine textured sediments. Future research should focus on streams whose watersheds are predominantly impacted by UOG pipeline, UOG wells, or land use classified as oil and gas barren to fully understand which observed impacts may be attributed to specific types of UOG development. When selecting sampling locations, effort should be placed on minimizing spatial variability between sampling points and nearby UOG development. Watershed attributes, such as slope, should be characterized to determine how it may augment the impact of UOG development on streams. Lastly, in addition to the analyses performed in this study, future studies should determine stream sediment chemistry. This could allow for the discovery of further environmental changes that may be attributed to UOG development and how they may influence microbial community composition and function.

The sensitivity of microorganisms to environmental conditions, along with the ease and affordability of modern sequencing, has led to burgeoning interest in the use microorganisms as indicators of water quality (Proia et al., 2012, Staly et al., 2014, Tan et al., 2015). We observed a decline in the relative abundance of many bacterial families in response to both UOG impact levels (Fig. 7). This suggests that microorganisms are sensitive to the environmental changes related to UOG development and may serve as effective bioindicators of ecosystem effects associated with these operations. Flavobacteriaceae and Acidimicrobiia fm., in sediment and biofilm samples, respectively, had particularly strong responses to UOG development (Fig. 7), suggesting they may be useful indicators of UOG associated impacts.

\section{Conclusion}

The results of the survey study indicate that UOG development impacts headwater streams. Our results suggest that impacts are not from produced water but likely derive from land disturbance and deforestation associated with UOG development. Shifts in sediment texture were associated with altered biofilm community composition and sediment community function. Deforestation associated with constructing UOG infrastructure potentially allows more light to reach streams by reducing canopy cover. Increased temperature, likely due to increased light availability, appears to alter biofilm diversity and composition. These changes may shift carbon utilization, influence decomposition rates, and alter carbon transfer to higher trophic levels, 
thereby changing broader ecosystem function. Attempts should be made to leave riparian zone vegetation intact and prevent soil runoff during UOG development as means to mitigate stream warming and fine sediment delivery to nearby streams. 


\section{Tables}

Table 1 Mean \pm SD of water physiochemical properties for streams used in the microcosm experiment. Ten Mile and Whitely were averaged using monthly values since 2009, while White Day was averaged using monthly values since 2010 . Values with differing accompanying letters are significantly different. Concentrations below detection limit were excluded from analyses (Kruskal-Wallis and Dunn's Test post hoc).

\begin{tabular}{|c|c|c|c|c|c|c|}
\hline \multirow[b]{2}{*}{ Water Physiochemical } & \multicolumn{2}{|l|}{ White Day } & \multicolumn{2}{|l|}{ Ten Mile } & \multicolumn{2}{|l|}{ Whitely } \\
\hline & & & & & & \\
\hline $\mathrm{EC}(\mu \mathrm{S} / \mathrm{cm})$ & $109.95 \pm 61.44$ & $a$ & $690.10 \pm 444.84$ & $b$ & $1760.49 \pm 1413.26$ & $c$ \\
\hline Temperature $\left({ }^{\circ} \mathrm{C}\right)$ & $13.12 \pm 8.82$ & & $12.89 \pm 8.47$ & & $12.45 \pm 7.21$ & \\
\hline $\operatorname{TDS}(\mathrm{mg} / \mathrm{L})^{* *}$ & $63.46 \pm 100.53$ & $a$ & $347.74 \pm 183.41$ & $b$ & $948.39 \pm 708.74$ & $c$ \\
\hline Alkalinity & $31.41 \pm 21.30$ & $a$ & $132.16 \pm 31.67$ & $b$ & $213.01 \pm 96.47$ & $c$ \\
\hline Acid (mg/L) & $0.60 \pm 0.83$ & $a$ & $1.20 \pm 2.91$ & $b$ & $0.62 \pm 1.11$ & $c$ \\
\hline $\mathrm{pH}$ & $7.63 \pm 0.76$ & $a$ & $7.88 \pm 0.71$ & $b$ & $8.13 \pm 0.35$ & $c$ \\
\hline Discharge Velocity (cfs) & $48.46 \pm 54.61$ & $a$ & $171.19 \pm 318.96$ & $b$ & $174.27 \pm 321.42$ & $b$ \\
\hline \multicolumn{7}{|l|}{ Major Ions (mg/L) } \\
\hline Sulfate & $24.34 \mid \pm 89.97$ & $a$ & $154.55 \pm 115.49$ & $b$ & $596.58 \pm 514.35$ & $c$ \\
\hline Calcium & $13.48 \pm 10.81$ & $a$ & $57.12 \pm 14.83$ & $b$ & $82.88 \pm 33.48$ & $c$ \\
\hline Chloride & $6.89 \pm 5.61$ & $a$ & $57.16 \pm 49.96$ & $b$ & $128.47 \pm 136.53$ & c \\
\hline Bromine & $0.10 \pm 0.14$ & $a$ & $0.39 \pm 0.59$ & $b$ & $1.06 \pm 1.47$ & $c$ \\
\hline Magnesium & $2.86 \pm 2.74$ & $a$ & $12.43 \pm 5.47$ & $b$ & $32.98 \pm 15.95$ & $c$ \\
\hline Sodium & $57.12 \pm 7.79$ & $a$ & $83.13 \pm 73.16$ & $b$ & $308.82 \pm 328.06$ & $c$ \\
\hline \multicolumn{7}{|l|}{ Minor Ions $(\mu \mathrm{g} / \mathrm{L})$} \\
\hline Iron & $105.17 \pm 129.39$ & $a$ & $145.29 \pm 311.52$ & $b$ & $97.53 \pm 185.75$ & $c$ \\
\hline Manganese & $25.70 \pm 31.12$ & $a$ & $169.72 \pm 1330.51$ & $b$ & $43.73 \pm 30.09$ & $c$ \\
\hline Aluminum & $50.68 \pm 84.75$ & $a$ & $109.49 \pm 195.51$ & $b$ & $64.50 \pm 152.32$ & $a$ \\
\hline
\end{tabular}

*Electrical Conductivity

**Total Dissolved Solids 
Table 2 Mean \pm SD of stream sediment and water physiochemical properties by impact level. Lower case letters indicate significant differences (ANOVA and Fisher's Least Significant Difference post hoc or Kruskal-Wallis and Dunn's Test post hoc).

\begin{tabular}{|c|c|c|c|c|c|c|}
\hline & Non-Impacted & & Impacted & & Highly Impacted & \\
\hline \multicolumn{7}{|c|}{ Sediment Physiochemical } \\
\hline $\mathrm{EC}(\mu \mathrm{S} / \mathrm{cm})^{*}$ & $141.25 \pm 102.04$ & & $194.29 \pm 69.25$ & & $138.33 \pm 68.34$ & \\
\hline Redox (mV) & $-47.63 \pm 6.25$ & & $-52.57 \pm 17.31$ & & $-43.08 \pm 18.11$ & \\
\hline $\mathrm{pH}$ & $7.24 \pm 0.12$ & & $7.33 \pm 0.32$ & & $7.16 \pm 0.32$ & \\
\hline $\mathrm{OM}(\%)^{* *}$ & $3.95 \pm 0.50$ & & $4.01 \pm 0.71$ & & $4.19 \pm 0.49$ & \\
\hline Sand $(\%)$ & $88.49 \pm 5.27$ & & $79.14 \pm 12.13$ & & $81.79 \pm 8.98$ & \\
\hline Silt (\%) & $8.81 \pm 3.59$ & & $16.10 \pm 9.32$ & & $12.63 \pm 6.65$ & \\
\hline Clay $(\%)$ & $2.69 \pm 2.44$ & & $4.76 \pm 3.31$ & & $5.59 \pm 3.19$ & \\
\hline \multicolumn{7}{|l|}{ Water Physiochemical } \\
\hline $\mathrm{EC}(\mu \mathrm{S} / \mathrm{cm})$ & $196.63 \pm 93.18$ & $a$ & $320.57 \pm 145.42$ & $b$ & $211.00 \pm 36.25$ & $a$ \\
\hline Redox (mV) & $-70.13 \pm 23.83$ & & $-91.71 \pm 16.64$ & & $-76.42 \pm 19.65$ & \\
\hline Temperature $\left({ }^{\circ} \mathrm{C}\right)$ & $20.47 \pm 1.45$ & $a$ & $19.56 \pm 3.37$ & $a$ & $22.64 \pm 1.90$ & $b$ \\
\hline $\operatorname{TDS}(\mathrm{mg} / \mathrm{L})^{* * *}$ & $125.25 \pm 41.37$ & $a$ & $197.14 \pm 90.40$ & $b$ & $128.42 \pm 22.50$ & $a$ \\
\hline Alkalinity & $75.76 \pm 24.93$ & $a$ & $121.20 \pm 35.21$ & $b$ & $83.71 \pm 16.68$ & $a$ \\
\hline $\mathrm{pH}$ & $7.84 \pm 0.39$ & & $8.16 \pm 0.28$ & & $7.75 \pm 0.37$ & \\
\hline \multicolumn{7}{|l|}{ Major lons (mg/L) } \\
\hline Sulfate & $14.37 \pm 6.61$ & & $23.56 \pm 23.51$ & & $13.87 \pm 8.28$ & \\
\hline Calcium & $29.13 \pm 10.64$ & $a$ & $48.61 \pm 17.22$ & $b$ & $28.93 \pm 6.01$ & $a$ \\
\hline Chloride & $6.51 \pm 8.38$ & & $12.23 \pm 14.58$ & & $3.22 \pm 2.52$ & \\
\hline Magnesium & $5.72 \pm 2.02$ & & $7.59 \pm 3.16$ & & $5.46 \pm 1.18$ & \\
\hline Potassium & $1.80 \pm 0.35$ & & $1.83 \pm 0.43$ & & $1.94 \pm 0.29$ & \\
\hline Sodium & $7.17 \pm 4.78$ & & $9.52 \pm 7.24$ & & $5.55 \pm 1.08$ & \\
\hline Nitrogen & $0.40 \pm 0.49$ & & $0.51 \pm 0.44$ & & $0.59 \pm 0.59$ & \\
\hline Strontium & $0.12 \pm 0.06$ & & $0.18 \pm 0.10$ & & $0.15 \pm 0.04$ & \\
\hline \multicolumn{7}{|l|}{ Minor Ions $(\mu \mathrm{g} / \mathrm{L})$} \\
\hline Barium & $45.45 \pm 10.66$ & & $57.22 \pm 18.82$ & & $54.57 \pm 11.44$ & \\
\hline Iron & $20.13 \pm 10.12$ & & $19.57 \pm 10.44$ & & $45.17 \pm 47.95$ & \\
\hline Manganese & $11.31 \pm 19.33$ & & $10.86 \pm 9.79$ & & $39.58 \pm 63.61$ & \\
\hline Aluminum & $26.13 \pm 31.77$ & & $15.86 \pm 13.36$ & & $17.25 \pm 11.71$ & \\
\hline Phosphorus & $18.75 \pm 10.94$ & & $37.14 \pm 38.06$ & & $14.58 \pm 12.33$ & \\
\hline Zinc & $10.00 \pm 16.72$ & & $16.29 \pm 35.64$ & & $4.08 \pm 3.42$ & \\
\hline
\end{tabular}

*Electrical Conductivity

** Organic Matter

***Total Dissolved Solids 


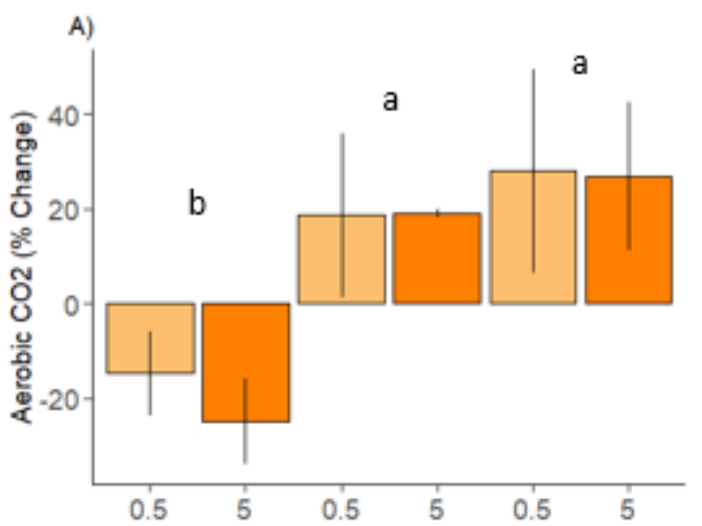

\section{Figures}
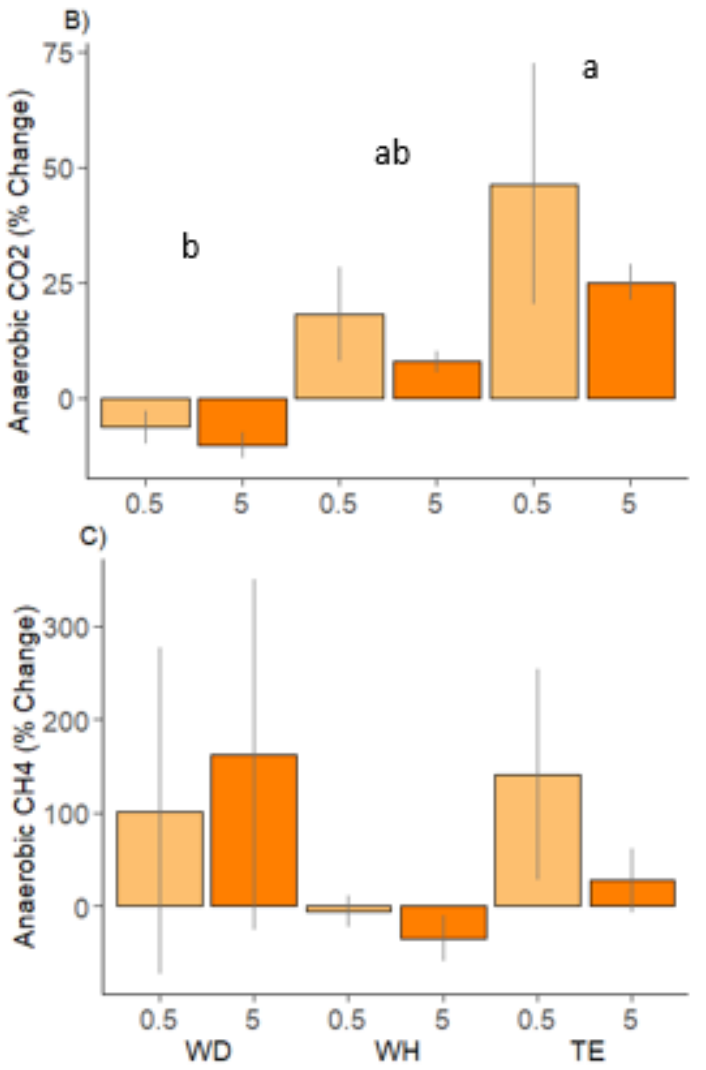

Figure 1 Percent change in aerobic $\mathrm{CO}_{2}(\mathrm{~A})$, anaerobic $\mathrm{CO}_{2}(\mathrm{~B})$ and anaerobic $\mathrm{CH}_{4}(\mathrm{C})$ production in response to $0.5 \%$ and $5 \%$ produced water addition relative to microcosms that did not receive any produced water. Effects were examined in three streams: White Day (WD), Whitely (WH) and Ten Mile (TE). Significant differences between sites are indicated by lowercase letters ( ANOVA and Fisher's LSD, $\alpha=0.05$ ). 


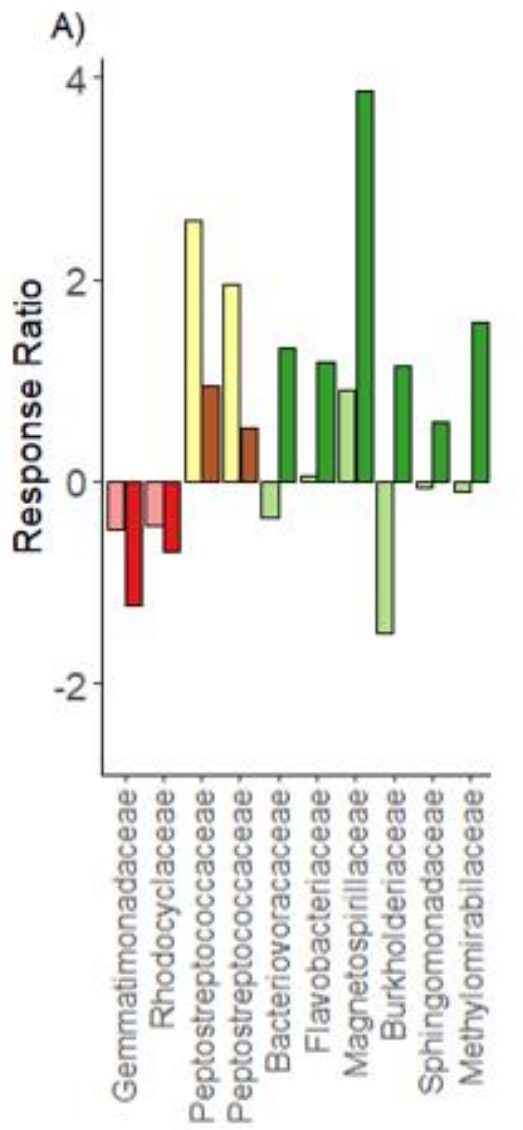

Family

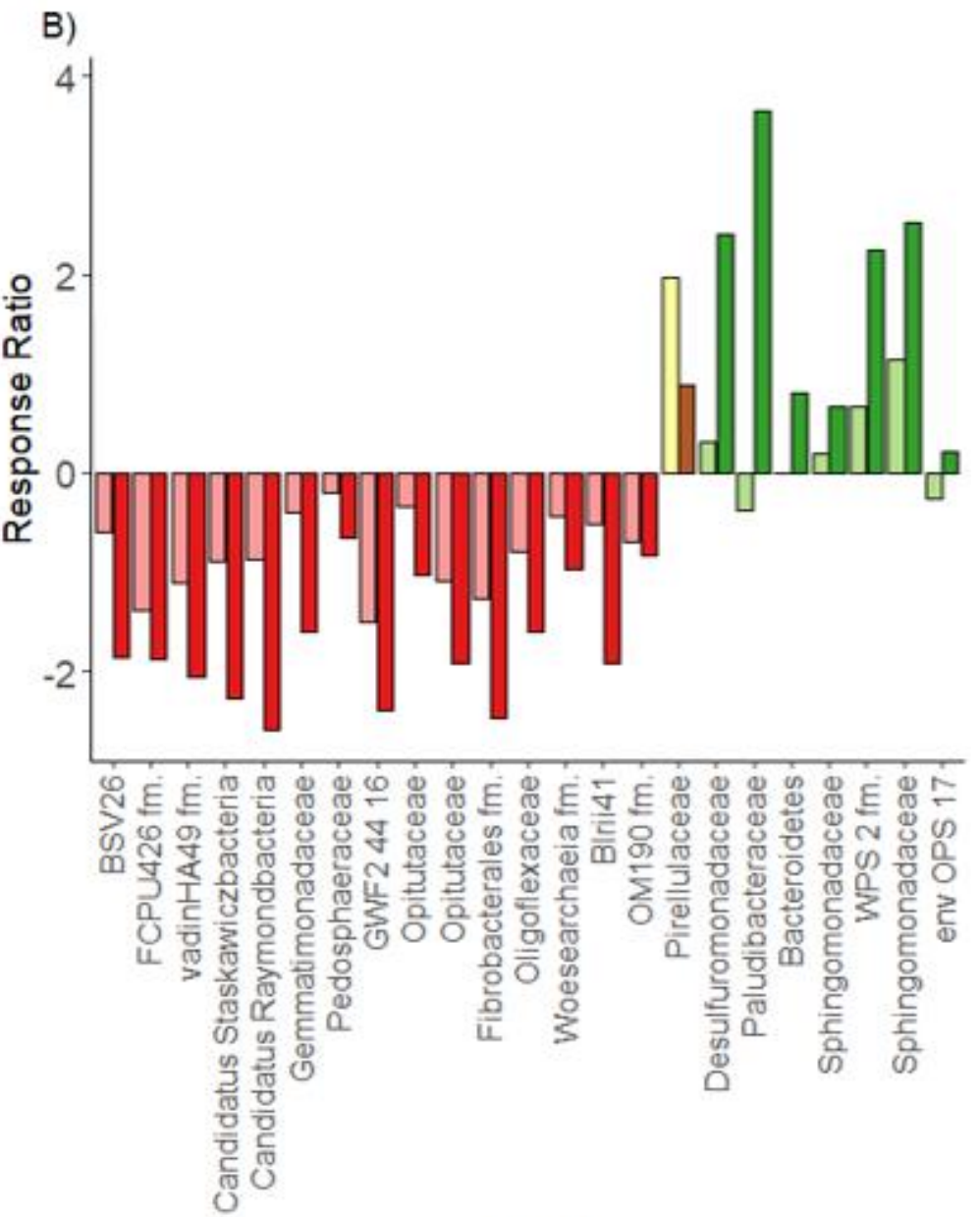

Family

Figure 2 Response ratio reflecting changes in the relative abundance of indicator families in aerobic (A) and anaerobic (B) microcosm sediments in response to $0.5 \%$ (lighter shade) and 5\% (darker shade) produced water. Families were identified as indicators of $0 \%$ (red), $0.5 \%$ (brown), and 5\% (green) produced water using Dufrêne-Legendre Indicator Species Analysis $(\alpha=0.01)$ 

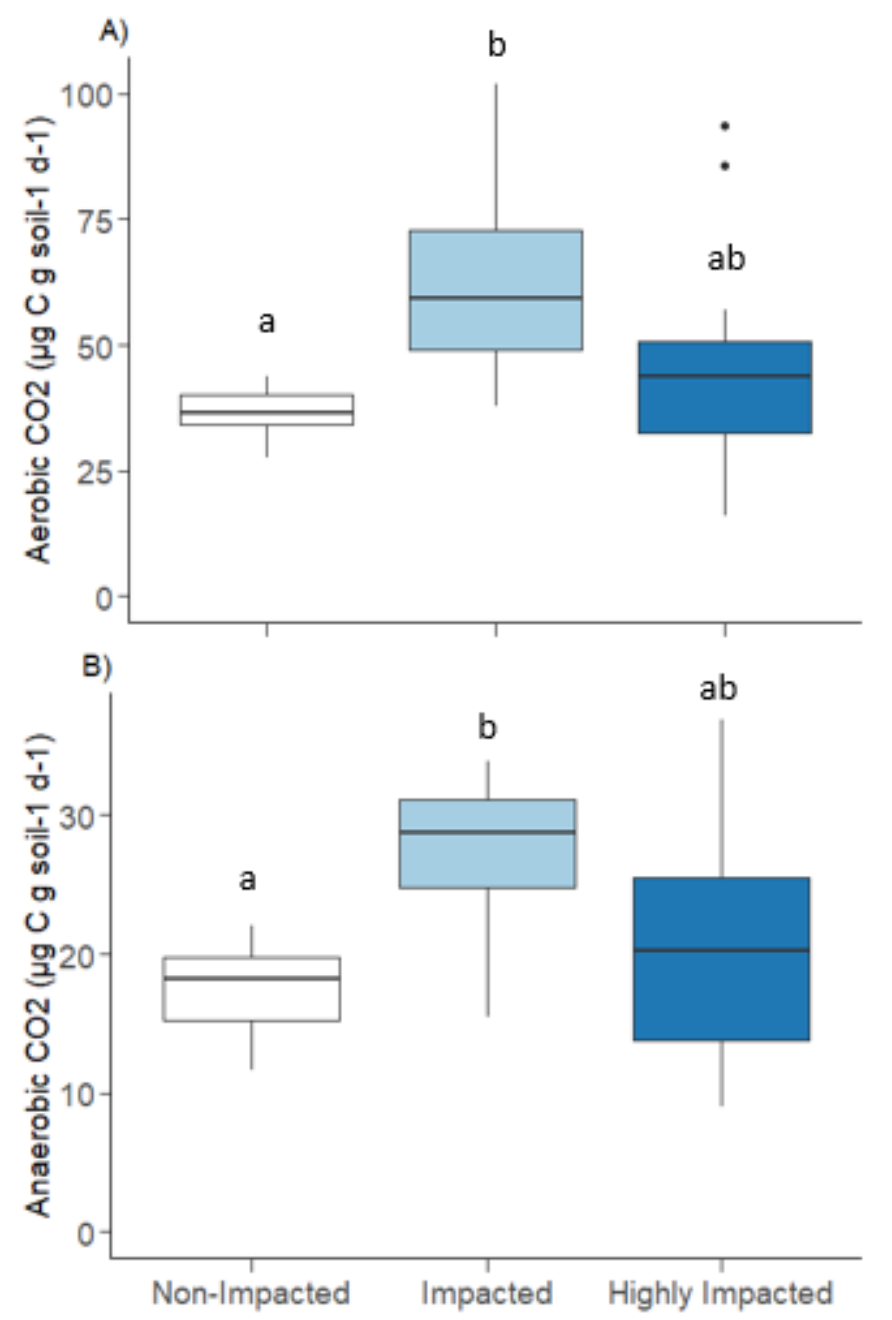

Figure 3 Box plots of aerobic (A) and anaerobic (B) $\mathrm{CO}_{2}$ production by stream sediments from watersheds with varying levels of UOG development. 

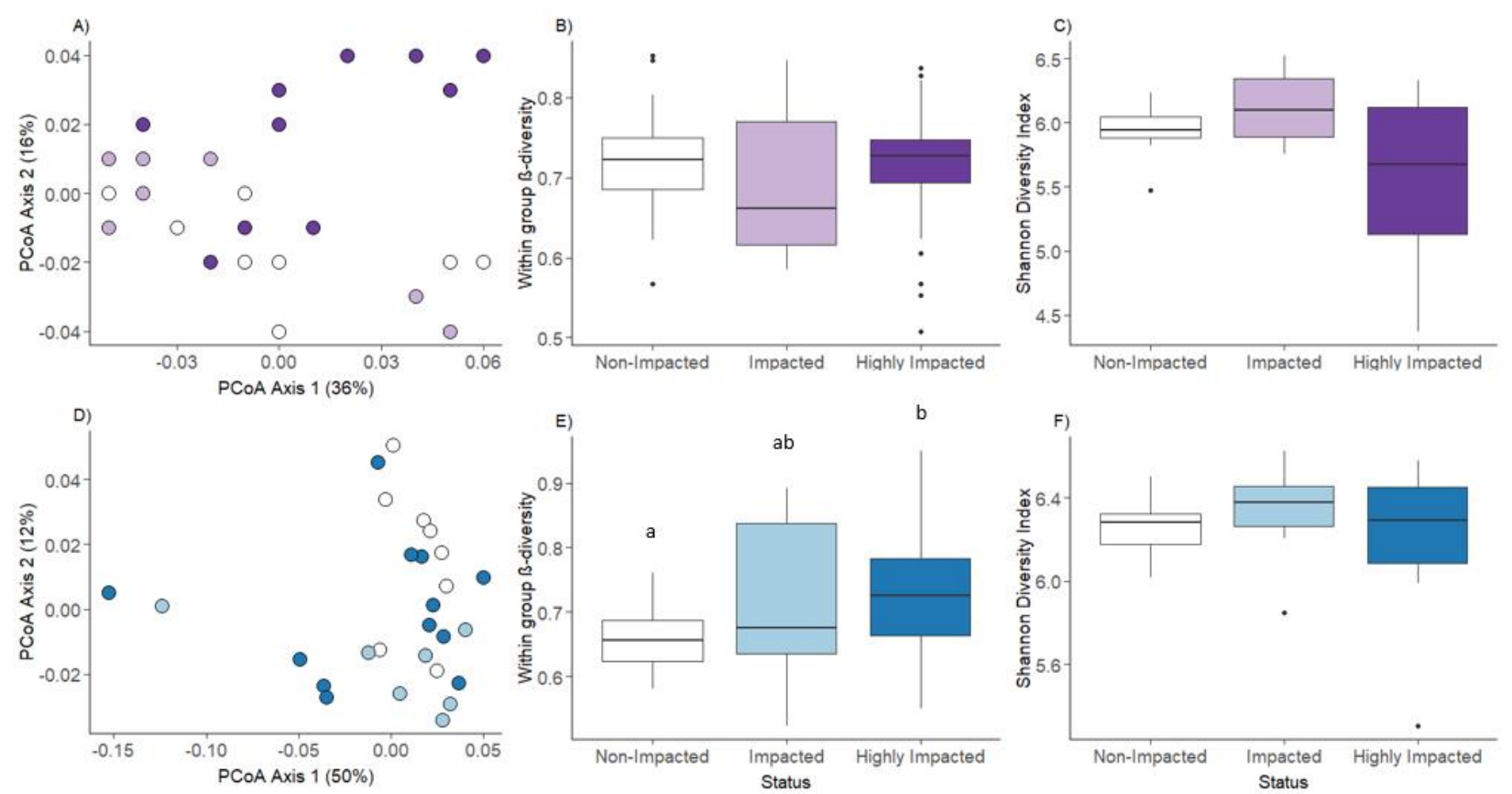

Figure 4 Community composition of biofilm (top row) and sediment (bottom row) in nonimpacted (no fill), impacted (lighter color), and highly impacted (darker color) streams represented by PCoA plots (A and D), within group $\beta$-diversity (B and E), and Shannon Diversity Index (C and F). Fisher's Least Significant Difference (LSD) Test in Analysis of Variance (ANOVA) indicated that the within group $\beta$-diversity of sediment in highly impacted streams was significantly different than that of non-impacted streams (lowercase letters). FlignerKilleen Test of Homogeneity of Variances revealed greater variance in the Shannon Diversity Index of highly impacted biofilm communities compared to non-impacted and impacted streams. 


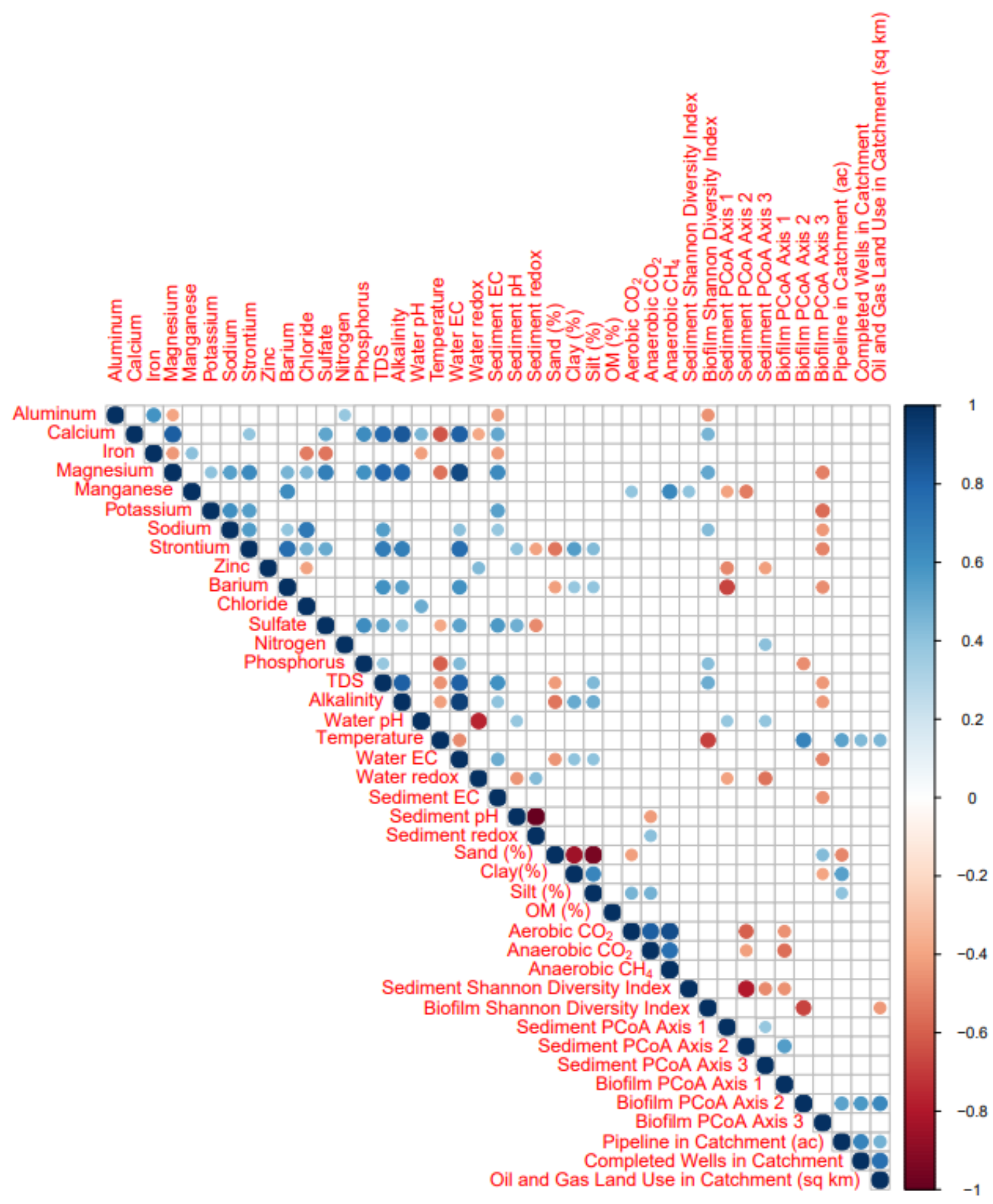

Figure 5 Spearman correlation matrix of sediment and water physiochemical properties, microbial parameters, and UOG development data. 

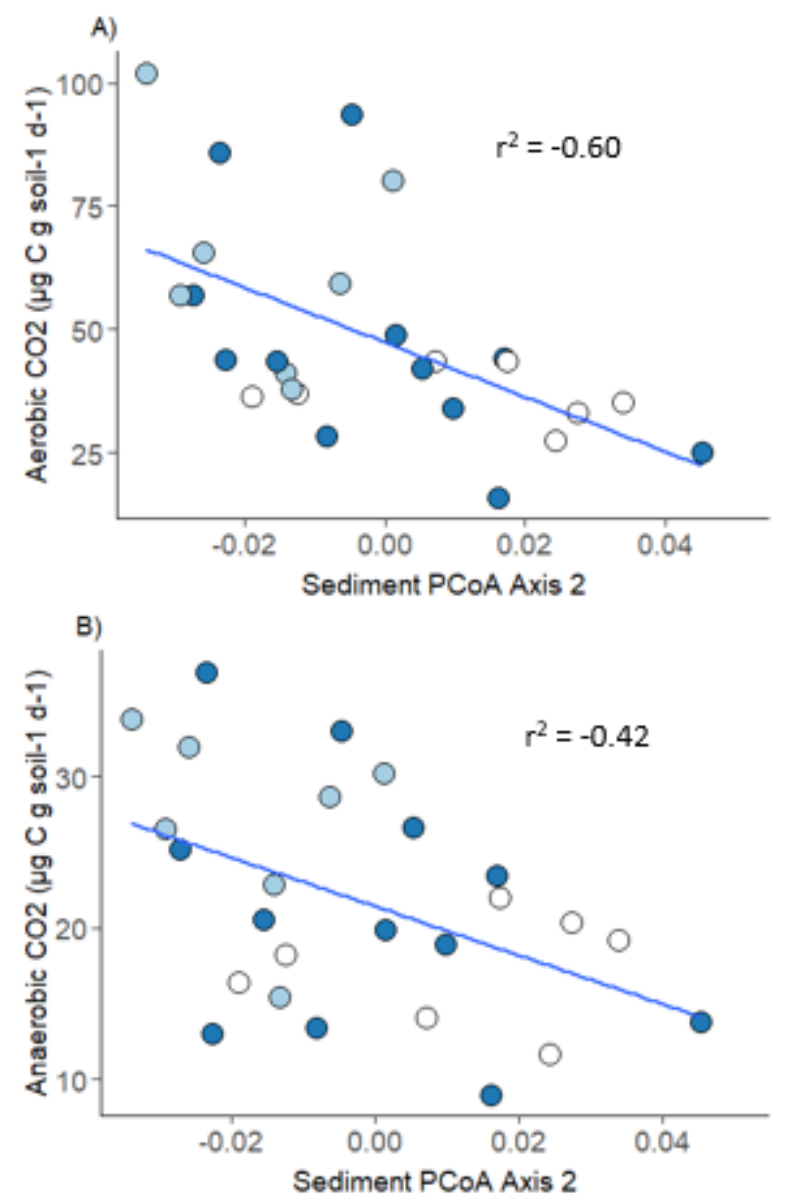

Figure 6 Correlation of aerobic (A) and anaerobic (B) $\mathrm{CO}_{2}$ production and sediment microbial community composition (represented by sediment PCoA Axis 2). 
A)

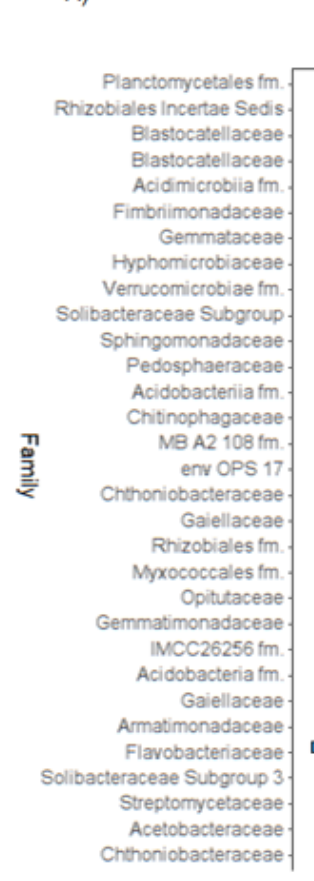

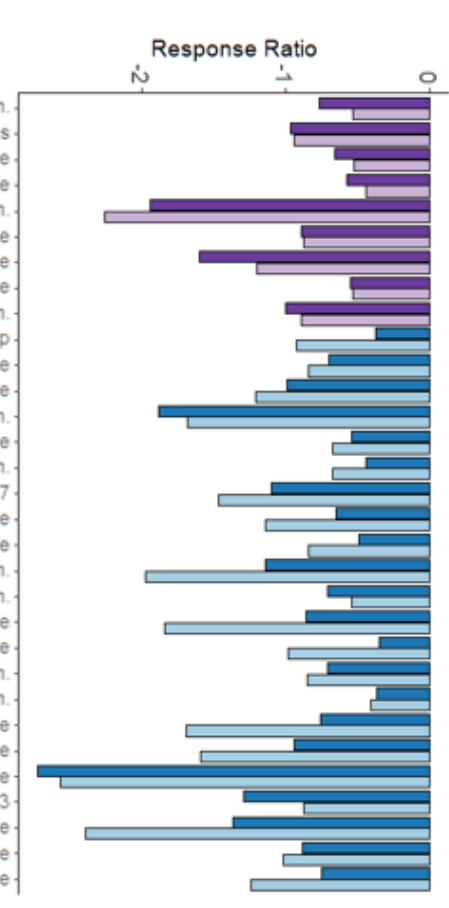

B)

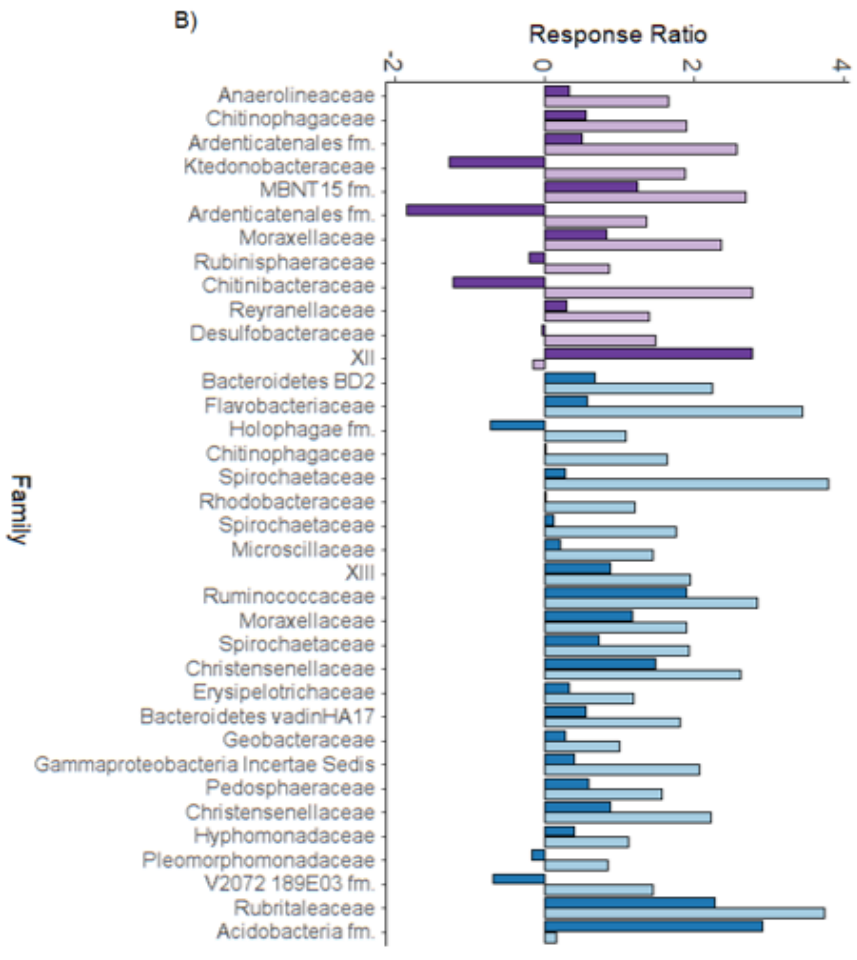

Figure 7 Response ratio reflecting changes in the relative abundance of families in impacted (lighter shade) and highly impacted (darker shade) streams relative to non-impacted streams. Indicators identified using the Dufrêne-Legendre Indicator Species Analysis $(\alpha=0.01)$ of nonimpacted (A) or impacted and highly impacted (B) streams are shown for sediment (blue) and biofilm (purple) communities. 


\section{References}

Allan, D., Erickson, D., \& Fay, J. (1997). The influence of catchment land use on stream integrity across multiple spatial scales. Freshwater biology, 37(1), 149-161.

Amir, A., McDonald, D., Navas-Molina, J. A., Kopylova, E., Morton, J. T., Xu, Z. Z., ... \& Knight, R. (2017). Deblur rapidly resolves single-nucleotide community sequence patterns. MSystems, 2(2).

Ancion, P. Y., Lear, G., Dopheide, A., \& Lewis, G. D. (2013). Metal concentrations in stream biofilm and sediments and their potential to explain biofilm microbial community structure. Environmental pollution, 173, 117-124.

Anderson, M. J. (2001). A new method for non-parametric multivariate analysis of variance. Austral ecology, 26(1), 32-46.

Anderson, M. J. (2014). Permutational multivariate analysis of variance (PERMANOVA). Wiley statsref: statistics reference online, 1-15.

Anderson, T. H., \& Domsch, A. K. (1993). The metabolic quotient for CO2 (qCO2) as a specific activity parameter to assess the effects of environmental conditions, such as $\mathrm{pH}$, on the microbial biomass of forest soils. Soil Biology \& Biochemistry, 25(3), 393-395.

Bartlett, M. S. (1937). Properties of sufficiency and statistical tests. Proceedings of the Royal Society of London. Series A-Mathematical and Physical Sciences, 160(901), 268-282.

Battin, T. J., Besemer, K., Bengtsson, M. M., Romani, A. M., \& Packmann, A. I. (2016). The ecology and biogeochemistry of stream biofilms. Nature Reviews Microbiology, 14(4), 251.

Bengtsson, M. M., Sjøtun, K., \& Øvreås, L. (2010). Seasonal dynamics of bacterial biofilms on the kelp Laminaria hyperborea. Aquatic Microbial Ecology, 60(1), 71-83.

Bengtsson, M. M., Wagner, K., Schwab, C., Urich, T., \& Battin, T. J. (2018). Light availability impacts structure and function of phototrophic stream biofilms across domains and trophic levels. Molecular ecology, 27(14), 2913-2925.

Bernal, S., Lupon, A., Ribot, M., Sabater, F., \& Martí, E. (2015). Riparian and in-stream controls on nutrient concentrations and fluxes in a headwater forested stream. Biogeosciences 12, 1941-1954.

Bokulich, N. A., Kaehler, B. D., Rideout, J. R., Dillon, M., Bolyen, E., Knight, R., ... \& Caporaso, J. G. (2018). Optimizing taxonomic classification of marker-gene amplicon sequences with QIIME 2's q2-feature-classifier plugin. Microbiome, 6(1), 90.

Bolyen, E., Rideout, J. R., Dillon, M. R., Bokulich, N. A., Abnet, C. C., Al-Ghalith, G. A., ... \& Bai, Y. (2019). Reproducible, interactive, scalable and extensible microbiome data science using QIIME 2. Nature biotechnology, 37(8), 852-857. 
Bouma, T. J., \& Bryla, D. R. (2000). On the assessment of root and soil respiration for soils of different textures: interactions with soil moisture contents and soil $\mathrm{CO} 2$ concentrations. Plant and Soil, 227(1-2), 215-221.

Brittingham, M. C., Maloney, K. O., Farag, A. M., Harper, D. D., \& Bowen, Z. H. (2014). Ecological risks of shale oil and gas development to wildlife, aquatic resources and their habitats. Environmental science \& technology, 48(19), 11034-11047.

Catalán, N., Kellerman, A. M., Peter, H., Carmona, F., \& Tranvik, L. J. (2015). Absence of a priming effect on dissolved organic carbon degradation in lake water. Limnology and Oceanography, 60(1), 159-168.

Chambers, J. M., Freeny, A. E., \& Heiberger, R. M. (2017). Analysis of variance; designed experiments. In Statistical models in $S$ (pp. 145-193). Routledge.

Christensen, B. T., \& Sørensen, L. H. (1985). The distribution of native and labelled carbon between soil particle size fractions isolated from long-term incubation experiments. Journal of Soil Science, 36(2), 219-229.

Collins, S. M., Sparks, J. P., Thomas, S. A., Wheatley, S. A., \& Flecker, A. S. (2016). Increased light availability reduces the importance of bacterial carbon in headwater stream food webs. Ecosystems, 19(3), 396-410.

Conover, W. J., Johnson, M. E., \& Johnson, M. M. (1981). A comparative study of tests for homogeneity of variances, with applications to the outer continental shelf bidding data. Technometrics, 23(4), 351-361.

Cook, P. G., Walker, G. R., \& Jolly, I. D. (1989). Spatial variability of groundwater recharge in a semiarid region. Journal of hydrology, 111(1-4), 195-212.

Couceiro, S. R. M., Hamada, N., Forsberg, B. R., \& Padovesi-Fonseca, C. (2010). Effects of anthropogenic silt on aquatic macroinvertebrates and abiotic variables in streams in the Brazilian Amazon. Journal of Soils and Sediments, 10(1), 89-103.

Davies-Colley, R. J., Hickey, C. W., Quinn, J. M., \& Ryan, P. A. (1992). Effects of clay discharges on streams. Hydrobiologia, 248(3), 215-234.

De Mendiburu, F. (2020). Agricolae: statistical procedures for agricultural research. R package version 1.3-2.

Dilustro, J. J., Collins, B., Duncan, L., \& Crawford, C. (2005). Moisture and soil texture effects on soil $\mathrm{CO} 2$ efflux components in southeastern mixed pine forests. Forest Ecology and Management, 204(1), 87-97.

Dufrêne, M., \& Legendre, P. (1997). Species assemblages and indicator species: the need for a flexible asymmetrical approach. Ecological monographs, 67(3), 345-366.

Dunn, O. J. (1964). Multiple comparisons using rank sums. Technometrics, 6(3), 241-252.

Eggleton, J., \& Thomas, K. V. (2004). A review of factors affecting the release and bioavailability of contaminants during sediment disturbance events. Environment international, 30(7), 973-980. 
Ely, D. T., Von Schiller, D., \& Valett, H. M. (2010). Stream acidification increases nitrogen uptake by leaf biofilms: implications at the ecosystem scale. Freshwater Biology, 55(6), 1337-1348.

England, L. E., \& Rosemond, A. D. (2004). Small reductions in forest cover weaken terrestrial aquatic linkages in headwater streams. Freshwater biology, 49(6), 721-734.

Excoffier, L., Smouse, P. E., \& Quattro, J. M. (1992). Analysis of molecular variance inferred from metric distances among DNA haplotypes: application to human mitochondrial DNA restriction data. Genetics, 131(2), 479-491.

Fellows, C. S., Valett, H. M., Dahm, C. N., Mulholland, P. J., \& Thomas, S. A. (2006). Coupling nutrient uptake and energy flow in headwater streams. Ecosystems, 9(5), 788-804.

Feris, K., Ramsey, P., Frazar, C., Moore, J. N., Gannon, J. E., \& Holben, W. E. (2003). Differences in hyporheic-zone microbial community structure along a heavy-metal contamination gradient. Applied and Environmental Microbiology, 69(9), 5563-5573.

Fisher, R. A., Corbet, A. S., \& Williams, C. B. (1943). The relation between the number of species and the number of individuals in a random sample of an animal population. The Journal of Animal Ecology, 42-58.

Gallegos, T. J., Varela, B. A., Haines, S. S., \& Engle, M. A. (2015). Hydraulic fracturing water use variability in the United States and potential environmental implications. Water Resources Research, 51(7), 5839-5845.

Giménez, R., Mercau, J., Nosetto, M., Páez, R., \& Jobbágy, E. (2016). The ecohydrological imprint of deforestation in the semiarid Chaco: insights from the last forest remnants of a highly cultivated landscape. Hydrological Processes, 30(15), 2603-2616.

Gray, L. J., \& Ward, J. V. (1982). Effects of sediment releases from a reservoir on stream macroinvertebrates. Hydrobiologia, 96(2), 177-184.

Hamarashid, N. H., Othman, M. A., \& Hussain, M. A. H. (2010). Effects of soil texture on chemical compositions, microbial populations and carbon mineralization in soil. Egyptian Journal of Experimental Biology (Botany), 6(1), 59-64.

Harjung, A., Perujo, N., Butturini, A., Romaní, A. M., \& Sabater, F. (2019). Responses of microbial activity in hyporheic pore water to biogeochemical changes in a drying headwater stream. Freshwater Biology, 64(4), 735-749.

Hawkins, C. P., Murphy, M. L., \& Anderson, N. H. (1982). Effects of canopy, substrate composition, and gradient on the structure of macroinvertebrate communities in Cascade Range streams of Oregon. Ecology, 63(6), 1840-1856.

Hill, B. H., Herlihy, A. T., \& Kaufmann, P. R. (2002). Benthic microbial respiration in Appalachian mountain, piedmont, and coastal plains streams of the eastern USA. Freshwater Biology, 47(2), 185-194. 
Hollander, M., \& Wolfe, D. A. (1973). Kendall and Spearman tests. Nonparametric Statistical Methods, 185-194.

Hurlbert, S. H. (1971). The nonconcept of species diversity: a critique and alternative parameters. Ecology, 52(4), 577-586.

Ilha, P., Schiesari, L., Yanagawa, F. I., Jankowski, K., \& Navas, C. A. (2018). Deforestation and stream warming affect body size of Amazonian fishes. PloS one, 13(5), e0196560.

Johnson, N., Gagnolet, T., Ralls, R., Zimmerman, E., Eichelberger, B., Tracey, C., ... \& Bearer, S. (2010). Pennsylvania energy impacts assessment report 1: Marcellus Shale natural gas and wind. Arlington, Virginia.

Kasting, J. F., \& Siefert, J. L. (2002). Life and the evolution of Earth's atmosphere. Science, 296(5570), 1066-1068.

Kelly, J. J., Häggblom, M., \& Tate Iii, R. L. (1999). Changes in soil microbial communities over time resulting from one time application of zinc: a laboratory microcosm study. Soil Biology and Biochemistry, 31(10), 1455-1465.

Kiviat, E. (2013). Risks to biodiversity from hydraulic fracturing for natural gas in the Marcellus and Utica shales. Annals of the New York Academy of Sciences, 1286(1), 1-14.

Lajeunesse, M. J. (2011). On the meta-analysis of response ratios for studies with correlated and multi-group designs. Ecology, 92(11), 2049-2055.

Lear, G., Anderson, M. J., Smith, J. P., Boxen, K., \& Lewis, G. D. (2008). Spatial and temporal heterogeneity of the bacterial communities in stream epilithic biofilms. FEMS Microbiology Ecology, 65(3), 463-473.

Legendre, P., \& Anderson, M. J. (1999). Distance-based redundancy analysis: testing multispecies responses in multifactorial ecological experiments. Ecological Monographs, 69(1), 1-24.

Leys, N. M., Ryngaert, A., Bastiaens, L., Verstraete, W., Top, E. M., \& Springael, D. (2004). Occurrence and phylogenetic diversity of Sphingomonas strains in soils contaminated with polycyclic aromatic hydrocarbons. Applied and Environmental Microbiology, 70(4), 1944-1955.

Li, Y., Zhu, J., Wang, L., Gao, Y., Zhang, W., Zhang, H., \& Niu, L. (2020). Grain size tunes microbial community assembly and nitrogen transformation activity under frequent hyporheic exchange: a column experiment. Water Research, 116040.

Lowe, W. H., \& Likens, G. E. (2005). Moving headwater streams to the head of the class. BioScience, 55(3), 196-197.

McArdle, B. H., \& Anderson, M. J. (2001). Fitting multivariate models to community data: a comment on distance-based redundancy analysis. Ecology, 82(1), 290-297.

McIlroy, S. J., Kirkegaard, R. H., Dueholm, M. S., Fernando, E., Karst, S. M., Albertsen, M., \& Nielsen, P. H. (2017). Culture-independent analyses reveal novel anaerolineaceae as 
abundant primary fermenters in anaerobic digesters treating waste activated sludge. Frontiers in microbiology, 8, 1134.

Meyer, L. D., Dabney, S. M., \& Harmon, W. C. (1995). Sediment-trapping effectiveness of stiff grass hedges. Transactions of the ASAE, 38(3), 809-815.

Morrissey, E. M., Jenkins, A. S., Brown, B. L., \& Franklin, R. B. (2013). Resource availability effects on nitrate-reducing microbial communities in a freshwater wetland. Wetlands, 33(2), 301-310.

Neubauer, S. C., Givler, K., Valentine, S., \& Megonigal, J. P. (2005). Seasonal patterns and plant-mediated controls of subsurface wetland biogeochemistry. Ecology, 86(12), 3334 3344.

Nuy, J. K., Lange, A., Beermann, A. J., Jensen, M., Elbrecht, V., Röhl, O., ... \& Boenigk, J. (2018). Responses of stream microbes to multiple anthropogenic stressors in a mesocosm study. Science of The Total Environment, 633, 1287-1301.

Ogle, D. H., Wheeler, P., \& Dinno, A. (2020). FSA: Fisheries Stock Analysis. R package version 0.8. 30 .

Oksanen, J., Blanchet, F. G., Kindt, R., Legendre, P., Minchin, P. R., O’Hara R.B., Simpson G.L., Solymos P., Stevens M.H. \& Wagner H. (2019) vegan: community ecology package. R package version 2.5-6.

Perujo, N., Sánchez-Vila, X., Proia, L., \& Romaní, A. M. (2017). Interaction between physical heterogeneity and microbial processes in subsurface sediments: a laboratory-scale column experiment. Environmental Science \& Technology, 51(11), 6110-6119.

Proia, L., Cassió, F., Pascoal, C., Tlili, A., \& Romaní, A. M. (2012). The use of attached microbial communities to assess ecological risks of pollutants in river ecosystems: the role of heterotrophs. In Emerging and Priority Pollutants in Rivers (pp. 55-83). Springer, Berlin, Heidelberg.

R Core Team (2020). R: A language and environment for statistical computing. R Foundation for Statistical Computing, Vienna, Austria.

Reemtsma, T., Bredow, A., \& Gehring, M. (1999). The nature and kinetics of organic matter release from soil by salt solutions. European Journal of Soil Science, 50(1), 53-64.

Rice, E.W., Baird, R.B., \& Eaton A.D. (Eds.). (2017). Standard methods for the examination of water and wastewater (23 ${ }^{\text {rd }}$ ed.). American Public Health Association, American Water Works Association, Water Environment Federation.

Roberts, D. W. (2019). labdsv: Ordination and multivariate analysis for ecology. R package version 2.0-1.

Rognes, T., Flouri, T., Nichols, B., Quince, C., \& Mahé, F. (2016). VSEARCH: a versatile open source tool for metagenomics. PeerJ, 4, e2584. 
Royston, J. P. (1982). Algorithm AS 181: the W test for normality. Journal of the Royal Statistical Society. Series C (Applied Statistics), 31(2), 176-180.

Royston, J. P. (1982b). An extension of Shapiro and Wilk's W test for normality to large samples Journal of the Royal Statistical Society: Series C (Applied Statistics), 31(2), 115-124.

Royston, P. (1995). Remark AS R94: A remark on algorithm AS 181: The W-test for normality. Journal of the Royal Statistical Society. Series C (Applied Statistics), 44(4), 547-551.

Sheridan, G. J., \& Noske, P. J. (2007). A quantitative study of sediment delivery and stream pollution from different forest road types. Hydrological Processes, 21(3), 387-398.

Sheridan, G. J., So, H. B., \& Loch, R. J. (2003). Improved slope adjustment functions for soil erosion prediction. Soil Research, 41(8), 1489-1508.

Staley, C., Gould, T. J., Wang, P., Phillips, J., Cotner, J. B., \& Sadowsky, M. J. (2014). Bacterial community structure is indicative of chemical inputs in the upper Mississippi river. Frontiers in microbiology, 5, 524.

Steel, R. G. D., \& Torrie, J. H. (1986). Principles and procedures of statistics: a biometrical approach. McGraw-Hill.

Tagart, J. V. (1984). Coho salmon survival from egg deposition to emergence. In Proceedings of the Olympic Wild Fish Conference, 1984. Peninsula College, Fisheries Technology Program.

Tan, B., Ng, C. M., Nshimyimana, J. P., Loh, L. L., Gin, K. Y. H., \& Thompson, J. R. (2015). Next-generation sequencing (NGS) for assessment of microbial water quality: current progress, challenges, and future opportunities. Frontiers in microbiology, 6, 1027.

Trexler, R., Solomon, C., Brislawn, C. J., Wright, J. R., Rosenberger, A., McClure, E. E., ... \& Hazen, T. C. (2014). Assessing impacts of unconventional natural gas extraction on microbial communities in headwater stream ecosystems in Northwestern Pennsylvania. Frontiers in microbiology, 5, 522.

Pfaff, J. D. (1993). Method 300.0 Determination of inorganic anions by ion chromatography. US Environmental Protection Agency, Office of Research and Development, Environmental Monitoring Systems Laboratory, 28.

United States Environmental Protection Agency (US EPA). (1994). Method 200.7:

Determination of metals and trace elements in water and wastes by inductively coupled plasma-atomic emission spectrometry Revision 4.4.

United States Environmental Protection Agency (US EPA). (1994). Method 200.8:

Determination of trace elements in waters and wastes by inductively coupled plasmamass spectrometry Revision 5.4. 
Vannote, R. L., Minshall, G. W., Cummins, K. W., Sedell, J. R., \& Cushing, C. E. (1980). The river continuum concept. Canadian journal of fisheries and aquatic sciences, 37(1), 130 137.

Vengosh, A., Jackson, R. B., Warner, N., Darrah, T. H., \& Kondash, A. (2014). A critical review of the risks to water resources from unconventional shale gas development and hydraulic fracturing in the United States. Environmental science \& technology, 48(15), 8334-8348.

Versantvoort, W., Guerrero-Cruz, S., Speth, D. R., Frank, J., Gambelli, L., Cremers, G., ... \& Reimann, J. (2018). Comparative genomics of Candidatus Methylomirabilis species and description of Ca. Methylomirabilis lanthanidiphila. Frontiers in microbiology, 9, 1672.

Wagner, K., Bengtsson, M. M., Findlay, R. H., Battin, T. J., \& Ulseth, A. J. (2017). High light intensity mediates a shift from allochthonous to autochthonous carbon use in phototrophic stream biofilms. Journal of Geophysical Research: Biogeosciences, 122(7), 1806-1820.

Warton, D. I., Wright, S. T., \& Wang, Y. (2012). Distance-based multivariate analyses confound location and dispersion effects. Methods in Ecology and Evolution, 3(1), 89-101.

Wichern, J., Wichern, F., \& Joergensen, R. G. (2006). Impact of salinity on soil microbial communities and the decomposition of maize in acidic soils. Geoderma, 137(1-2), 100 108.

Wong, V. N., Dalal, R. C., \& Greene, R. S. (2008). Salinity and sodicity effects on respiration and microbial biomass of soil. Biology and Fertility of Soils, 44(7), 943-953.

Yakimov, M. M., Denaro, R., Genovese, M., Cappello, S., D’Auria, G., Chernikova, T. N., ... \& Giluliano, L. (2005). Natural microbial diversity in superficial sediments of Milazzo harbor (Sicily) and community successions during microcosm enrichment with various hydrocarbons. Environmental Microbiology, 7(9), 1426-1441.

Ziemkiewicz, P., Quaranta, J. D., \& McCawley, M. (2014). Practical measures for reducing the risk of environmental contamination in shale energy production. Environmental Science: Processes \& Impacts, 16(7), 1692-1699. 